\title{
The effect of teaching practices on pre-service teachers' sense of efficacy belief and attitude towards teaching profession
}

\author{
Gökhan Baş ${ }^{* a}$, Cihad Şentürk ${ }^{* * b}$ \\ ${ }^{a}$ Niğde Ömer Halisdemir University, Faculty of Education, Niğde/Turkey \\ ${ }^{\mathrm{b}}$ Karamanoğlu Mehmetbey University, Faculty of Education, Karaman/Turkey
}

Article Info

DOI: $10.31704 /$ ijocis.2019.001

Article History:

Received 22 December 2018

Revised $\quad 30$ May 2019

Accepted 13 June 2019

Online $\quad 30$ June 2019

Keywords:

Teaching practices,

Sense of efficacy beliefs,

Teaching profession,

Pre-service teachers.

Article Type:

Research paper

\begin{abstract}
The purpose of this study was to examine the effect teaching practices on pre-service teachers' attitude towards teaching profession and sense of efficacy beliefs. The explanatory sequential design, which is one of the mixed methods research designs, was used in this study. The study group of this research consisted of pre-service teachers who were studying at Niğde Ömer Halisdemir University, Faculty of Education, Pedagogical Formation Training Certificate Programme $(n=14)$. While parametric test statistics were used in the analysis of the quantitative data, content analysis technique was employed in the analysis of the qualitative data. According to the results of the study, it was concluded that teaching practices have a statistically significant effect on the attitude of pre-service teachers towards the profession and that these practices were not effective in developing their sense of efficacy beliefs.
\end{abstract}

\section{Öğretmenlik uygulamalarının öğretmen adaylarının özyeterlik inancı ve öğretmenlik mesleğine yönelik tutumu üzerindeki etkisi}

\begin{tabular}{|c|c|}
\hline Makale B & \\
\hline DOI: 10.3 & 04/ijocis.2019.001 \\
\hline Makale $G$ & mişi: \\
\hline Geliş & 22 Aralık 2018 \\
\hline Düzeltme & 30 Mayıs 2019 \\
\hline Kabul & 13 Haziran 2019 \\
\hline Çevrimiçi & 30 Haziran 2019 \\
\hline $\begin{array}{l}\text { Anahtar K } \\
\text { Öğretmen } \\
\text { Özyeterlik } \\
\text { Öğretmen } \\
\text { Öğretmen }\end{array}$ & $\begin{array}{l}\text { imeler: } \\
\text { uygulamaları, } \\
\text { nancı, } \\
\text { dayları, } \\
\text { mesleği, }\end{array}$ \\
\hline $\begin{array}{l}\text { Makale Ti } \\
\text { Özgün Ma }\end{array}$ & \\
\hline
\end{tabular}

Öz

$\mathrm{Bu}$ araştırmanın amacı, öğretmenlik uygulamalarının öğretmen adaylarının mesleğe yönelik tutum ve özyeterlik inançları üzerindeki etkisini incelemektir. Bu araştırma bir karma yöntem araştırması olup, bu çalışmada karma yöntem araştırma desenlerinden biri olan açıklayıcı ardışık desen kullanılmıştır. Bu araştırmanın çalışma grubunu, Niğde Ömer Halisdemir Üniversitesi, Eğitim Fakültesi, Pedagojik Formasyon Eğitimi Sertifika Programında öğrenim görmekte olan öğretmen adayları $(n=14)$ teşkil etmiştir. Yapılan araştırmada, nicel verilerin analizinde parametrik test istatistikleri kullanılırken, nitel verilerin analizinde ise içerik analizi tekniği işe koşulmuştur. Araştırmada elde edilen sonuçlara göre, öğretmenlik uygulamalarının öğretmen adaylarının mesleğe yönelik tutumları üzerinde istatistiksel olarak anlamlı bir etkisinin olduğu sonucuna ulaşlırken, bu uygulamaların öğretmen adaylarının özyeterlik inançlarını geliştirmede etkili olmadığı sonucuna varılmıştır.
* Author: gokhanbas51@gmail.com
** Author: cihadsenturk@gmail.com
Orcid ID: https://orcid.org/0000-0002-9755-0003 Orcid ID: https://orcid.org/0000-0002-1276-8653 


\section{Introduction}

Based on the fact that the most important element of an education system is the teacher (Koç \& Demirel, 1999), it can be said that the teacher is both affected by the system and affects the system itself (Aslan \& Sağlam, 2017). Teachers are individuals who are in the cornerstone within the system to raise individuals in the desired quality (Özay-Köse, 2014). The teacher has an undeniable role in the development of the society and the training of qualified manpower (Aslan \& Sağlam, 2018). From this perspective, it can be said that teachers should be trained in a good way in reaching the desired goals in education (Kana, 2014). Therefore, teacher education has a very important place for the education system to reach the goals required by the era and to make the quality of education (Sağlam \& Kürüm, 2005). Not giving the necessary importance to teacher education will cause unqualified teachers to enter the system and this will most likely affect the education system negatively (Aslan \& Sağlam, 2018) because the changes made in the education system without raising qualified teachers cannot create the desired effect (Kana, 2014). In this context, it can be said that teacher education constitutes a significant part of education reforms (Ekinci \& Tican-Başaran, 2015) and teacher education is one of the factors that determine the quality of the education system (Oğuz, 2004). The fact that the teacher is the focus of improving the quality of the education system draws attention to teacher training programmes (Ekinci \& Tican-Başaran, 2015). Thus, the quality of the programmes employed in the training of pre-service teachers also closely affects the quality of teachers (Görgen, Çokçalışkan, \& Korkut, 2012). Therefore, it can be argued that the training they received before service is at the beginning of the variables that determine the quality of the education services that teachers perform (Sağır, Bilen, \& Ercan, 2014).

In the education system, teachers are expected to have some qualifications (Ministry of National Education [MoNE], 2017). In this respect, teachers need to undergo a good pre-service training process in order to have certain qualifications (Aslan \& Sağlam, 2018). Teaching practices constitute the most important aspect of the pre-service training (Koç \& Demirel, 1999). These practices are a very important university course giving prospective teachers an opportunity to put into practice what they have learned theoretically (Aslan \& Sağlam, 2017). This course has an important place in the development of teaching skills, due to the fact that teaching practices course that teacher candidates receive before the service presents them an opportunity to put into practice the theoretical knowledge they have (Sağır, Bilen, \& Ercan, 2014). The teaching practices course is implemented in order to put the theoretical knowledge which pre-service teachers have gained into practice before the service (Özkan, Albayrak, \& Berber, 2005), has an important place in determining the deficiencies of pre-service teachers (Kana, 2014) because they are being able to use the theoretical knowledge effectively and efficiently in the classroom is possible with sufficient application opportunities before the service (Harmandar, Bayrakçeken, Kıncal, Büyükkasap, \& Kızılkaya, 2000).

Practices applied by pre-service teachers in schools are of great importance in terms of developing skills related to general culture and pedagogical formation knowledge and content knowledge related to teaching profession (RIza \& Hamurcu, 2000). Teaching practices are an important support for the pre-service teachers to gain the competencies and responsibilities required by the profession (Koç \& Demirel, 1999). For this purpose, the Higher Education Council (HEC) has conducted various studies to provide the transfer of theoretical knowledge to the application in teacher education (Görgen, Çokçalışkan, \& Korkut, 2012). One of these studies is the teaching practice course that has been added to teacher training programmes to increase faculty-school cooperation (HEC, 1998). This course is designed to enable pre-service teachers to improve their knowledge and skills by applying them in a classroom environment within the scope of HEC-World Bank National Education Development Project (HEC, 1998). Teaching practices course has the quality that gives teachers a chance to apply the knowledge gained in the classes and to receive feedback from teachers/instructors and students (HEC, 2007). The most important purpose of these practices in schools is the introduction of the teaching profession and the mentor teachers' contribution to the professional development of pre-service teachers (Gökçe \& Demirhan, 2005). It is expected that teaching practices course, which has an important place in teacher education (Aslan \& Sağlam, 2017), also increases the positive attitude of pre-service teachers towards the profession (Özay-Köse, 2014) and improve their professional competence (Eker, 2015; Sağır, Bilen, \& Ercan, 2014). When pre-service teachers begin teaching profession, they should have a higher level of sense of efficacy belief to perform their duties effectively (Tschanen-Moran \& Hoy, 2001). If the teaching practices in the schools, which are the most effective way of establishing the sense of efficacy beliefs of pre-service teachers, become successful, these practices can contribute to make pre-service teachers feel competent (Öksüz \& Coşkun, 2012) because pre-service teachers improve sense of efficacy by seeing their strengths and weaknesses through teaching practices (Tschanen-Moran, Woolfolk-Hoy, \& Hoy, 1998). As a matter of fact, 
teaching practices have a quality that offers direct experiences to pre-service teachers (Tschanen-Moran \& Hoy, 2001). In this respect, it can be said that these practices, which offer direct experiences, can make significant contributions to the development of sense of efficacy beliefs of pre-service teachers (TschanenMoran, Woolfolk-Hoy, \& Hoy, 1998). In this context, teaching practices received during the pre-service training period can be defined as the most effective course in the development of the sense of efficacy beliefs of preservice teachers (Öksüz \& Coşkun, 2012). At the same time, one of the preconditions for individuals, who will perform the teaching profession, to fulfill the requirements of this profession more effectively is the attitude towards teaching profession (Bayrakdar, Vural-Batık, \& Barut, 2016). Based on the opinion that the attitude of the individuals towards their professions can affect their achievements in their professions positively or negatively (Semerci \& Semerci, 2004), it can be said that it is very important that pre-service teachers have positive attitude towards teaching in performing their duties when they begin the profession ( $\mathrm{NalçaCl} \&$ Sökmen, 2016). It is because pre-service teachers' positive attitude towards teaching profession will enable them to be more effective in performing this profession (Koç \& Demirel, 1999). The success of pre-service teachers in the profession depends on their love and willingness to practice this profession (Aydın \& Sağlam, 2012). It is unlikely that pre-service teachers will be able to perform this profession effectively and efficiently without having positive attitude towards the teaching profession (Çeliköz \& Çetin, 2004). In this sense, it is thought that teaching practices taken during the pre-service training period have an undeniable role in preservice teachers' positive attitude towards the profession (Şişman \& Acat, 2003). After all, teaching practices have an important place for pre-service teachers in gaining sense of efficacy (Bayrakdar, Vural-Batık, \& Barut, 2016), as well as developing positive attitudes towards teaching profession (Öksüz \& Coşkun, 2012).

Although it is stated that teaching practices have a very important place in developing sense of efficacy beliefs besides gaining positive attitudes towards the profession (Ben-Peretz, 2001), very little is known about the effects of teaching practices on pre-service teachers. Firstly, the research on the effect of teaching practices on the attitude of pre-service teachers towards the profession (Kılıç, 2004; Koç \& Demirel, 1999; Şişman \& Acat, 2003; Toprakçı, 2003) and sense of efficacy belief are limited (Aktağ, 2011; Sağır, Bilen, \& Ercan, 2014). Although teaching practices have a significant place in making pre-service teachers gain positive attitudes towards the profession, as well as develop their sense of efficacy belief (Ben-Peretz, 2001), little is known about this issue. Even though the research literature reports that teaching practices have a significant influence on the development of pre-service teachers' attitude towards the profession (Kılıç, 2004; Koç \& Demirel, 1999; Şişman \& Acat, 2003; Toprakçı, 2003) and their sense of efficacy belief (Aktağ, 2011; Sağır, Bilen, \& Ercan, 2014), this issue is contradictory in terms of the pre-service teachers taking pedagogical formation training. In Turkey, the need for teachers at the secondary level is generally met by the graduates of science-literature faculties. However, the fact that pedagogical formation training is tightened to a short period of time as a year raises questions about whether pre-service teachers have achieved the necessary competencies. Unlike the pre-service teachers studying at education faculties, the pre-service teachers taking pedagogical formation training are both taking courses about educational sciences and performing the teaching practices. This situation inevitably makes the quality of pedagogical formation training questionable in terms of raising qualified teachers. In this direction, the aim of this explanatory sequential mixed methods research (Creswell \& Plano-Clark, 2011; Tashakkori \& Teddlie, 1998) has been to reveal the effect and role of teaching practices on pre-service teachers' attitude towards the teaching profession and their sense of efficacy beliefs.

\section{Method}

\section{Research Design}

This study is a mixed methods research (Tashakkori \& Teddlie, 1998), which adopted explanatory sequential design, one of the mixed method research designs (Creswell \& Plano-Clark, 2011). The aim of the explanatory sequential pattern is to begin the research problem with the quantitative stage both for data collection and analysis and then to conduct qualitative study to explain the quantitative results (Creswell, 2012). The main rationale for using the explanatory pattern in this research is that different patterns have different strengths and weaknesses and that the data can be combined effectively to make use of these differences (Plano-Clark \& Ivankova, 2016). Therefore, in this study, the quantitative data were initially collected, then qualitative data were gathered to help explain and elaborate the quantitative findings. 


\section{Research Group}

The study group of this research consisted of the pre-service teachers ( $n=14)$ who were studying at the Pedagogical Formation Training Certificate Programme at the Faculty of Education of Niğde Ömer Halisdemir University in the spring term of the 2017-2018 academic year. Pre-service teachers, who constituted the study group, were also studying in the 4th year of the History Department of the Faculty of Science and Literature of the same university. $50 \%$ of the study group consisted of males $(n=7)$ and $\% 50$ consisted of $(n=7)$ females. In addition, the average mean age of the pre-service teachers participating in the research was $21(S D=.13)$.

\section{Procedure}

In the research, the pre-service teachers carried out teaching practices during a period of 14 weeks. The process in the research was put into practice in light of the programme proposed by the HEC. The pre-service teachers spent the first week of the research process with getting to know the school and the mentor; the next five weeks were spent by observation activities, and the last eight weeks by practice activities (see Table 1).

\section{Table 1.}

Process of Teaching Practices

\begin{tabular}{|c|c|}
\hline Week & Activities \\
\hline & 1. Term Plan \\
\hline \multirow{2}{*}{ 1. Week } & 2. Meeting with the group, introduction of the course and the practice school \\
\hline & 1. A day of the teacher at school \\
\hline 2. Week & 2. Instructional strategies the teacher uses \\
\hline \multirow[t]{2}{*}{ 3. Week } & 1. Teacher's classroom management and control \\
\hline & 1. Teacher in the constructivist approach \\
\hline \multirow{2}{*}{ 4. Week } & 2. Course activities and assessment of students \\
\hline & 1. Observation of questioning and materials and resources used at school \\
\hline 5. Week & 2. Making a course plan and observing a friend as a pre-service teacher \\
\hline \multirow[t]{2}{*}{ 6. Week } & 1. Observation of the teachers' teaching-learning process via observation form \\
\hline & 2. Making a course plan and observing a friend as a pre-service teacher \\
\hline 7. Week & 1. Making a course plan/observing a friend as a pre-service teacher /creating case data \\
\hline 8. Week & 1. Making a course plan/observing a friend as a pre-service teacher /creating case data \\
\hline 9. Week & 1. Making a course plan/observing a friend as a pre-service teacher /creating case data \\
\hline 10. Week & 1. Making a course plan/observing a friend as a pre-service teacher /creating case data \\
\hline 11. Week & 1. Making a course plan/observing a friend as a pre-service teacher /creating case data \\
\hline 12. Week & 1. Making a course plan/observing a friend as a pre-service teacher /creating case data \\
\hline 13. Week & 1. Making a course plan/observing a friend as a pre-service teacher /creating case data \\
\hline 14. Week & 1. Making a course plan/observing a friend as a pre-service teacher /creating case data \\
\hline
\end{tabular}

The first week of the study was completed with getting to know the group, getting information about the course, and introduction of the practice school. In the first week, accompanied with the lecturer conducting the research, the pre-service teachers also visited schools, where they would carry out the practices, and got to know about the school staff (school principal, mentor teachers, and other teachers). During this visit, the course days and hours that the pre-service teachers would carry out practices were determined. The preservice teachers spent two days in practice schools each week; they performed observation on the days that they did not carry out practice. They spent the first five weeks by observing and the last eight weeks by practice. Regarding the first five weeks, the pre-service teachers shared their observations with the lecturer; the observations conducted were discussed and inferences were made on how an effective and efficient course should be. After the observation process, the pre-service teachers went through the practice process.

Each pre-service teacher had the opportunity to practice at least one course hour every two weeks. The lesson plans of the pre-service teachers about the practice were reviewed by the lecturer every week and necessary feedback was provided to them. The lecturer evaluated the practices and had the opportunity to give feedback on the lesson plans, by spending at least one hour with the pre-service teachers every week. Besides this, the lecturer visited the practice schools from time to time to make observations on the pre-service teachers. The lecturer shared the results obtained from these observations with the pre-service teachers in the courses at the faculty of education and provided feedback regarding an effective lesson. In addition, the 
lecturer occasionally followed the course videos of the pre-service teachers and provided them with the feedback on the lessons.

\section{Data Collection Tools}

In the study, while "Attitude Scale towards Teaching Profession" and "Teachers' Sense of Efficacy Belief Scale" were used for the collection of quantitative data, the "observation form", "interview form", and "diary form" were used in collecting qualitative data. The explanatory information about the scale and forms used in the research were tried to be briefly described by addressing them under the titles of "quantitative data collection tools" and "qualitative data collection tools".

\section{Quantitative Data Collection Tools}

Attitude Scale towards Teaching Profession. "Attitude Scale towards Teaching Profession", developed by Üstüner (2006), was used to examine the pre-service teachers' attitude towards the teaching profession. The scale consists of a total of 34 items and all items are in 5-Point-Likert format $(1=$ strongly disagree; $2=$ disagree; 3 = neutral; 4 = agree; $5=$ strongly agree). While 14 of the items in the scale contain positive judgments, the remaining 10 items contain negative judgments. Besides this, the scale is one-dimensional (item 34; e.g., "I think I will be a knowledgeable and competent teacher"; $\alpha=.93$ ). In addition, the reliability coefficient obtained from the scale showed that the scale had an excellent value to be used in the study (Üstüner, 2006).

Teacher Sense of Efficacy Belief Scale. In order to examine the sense of efficacy beliefs of pre-service teachers, "Teacher Sense of Efficacy Belief Scale", developed by Tschanen-Moran and Hoy (2001) and adapted into Turkish by Çapa, Çakıroğlu, and Sarıkaya (2005), was used. The scale consist of a total of 24 items and all items are in 5-Point-Likert format ( 1 = strongly disagree; 2 = disagree; 3 = neutral; 4 = agree; $5=$ strongly agree). In addition, the scale is three-dimensional; (a) sense of efficacy regarding student engagement (item 8; e.g., "To what extent can you achieve to work with the difficult students? "; $\alpha=.82$ ), (b) sense of efficacy regarding instructional strategies (item 8, e.g., How well do you respond to the students' difficult questions? $\alpha=.86$ ), (c) sense of efficacy regarding classroom management (item 8; e.g., "How much can you control the behaviors that affect the course negatively in the classroom?"; $\alpha=.84)$. In addition, the reliability coefficients had good values for the scale to be used in the study. However, the results of the confirmatory factor analysis applied to the scale $(\mathrm{TLI}=.99 ; \mathrm{CFI}=.99 ; \mathrm{RMSEA}=.07)$ showed that the scale had acceptable values in order to be used (Çapa, Çakıroğlu, \& Sarıkaya, 2005).

\section{Qualitative Data Collection Tools}

Interview Form. The main aim of an interview is to collect information about a topic of interest or a question being wondered (Patton, 2002). Interview is required to learn about behaviours, feelings or how people express the world around them (Merriam, 1998). In this regard, it was thought to use the interview method, which is considered to contribute to collecting more meaningful data, in the diversification of data of the study (Creswell, 2013). Therefore, a semi-structured interview form was used in the study to examine the attitude of pre-service teachers towards the teaching profession and their sense of efficacy beliefs. In the preparation of the interview form, the literature review was made and the forms and scales related to the attitudes towards the teaching profession and the sense of efficacy beliefs were examined. A total of eight open-ended questions were prepared, in line with the form and scales studied on the basis of the scope. These questions were presented to the experts from the fields of linguistics and educational sciences; the questions were subjected to pilot application as a result of the feedback from these experts. In the study, the interview form was implemented in a group of five people consisting of different pre-service teachers; thus, the comprehensibility, usefulness, and the purpose of serving the questions were examined. Reviewing the prepared interview form after the pilot implementation, some revisions were made on the form (i.e., by adding probes to questions, changing the place of some questions, etc.) After the necessary changes were made, the interview form became ready to be used in the study.

Observation Form. Observation constitutes one of the basic methods used in qualitative research (Creswell, 2013). Observation defines the process of collecting the data needed by the research through monitoring by using people, society or a tool (Merriam, 1998). Observation, which is an important resource in qualitative data collection, is one of the main aids in clarifying the complexity of social events (Patton, 2002). For this purpose, a semi-structured observation form was used in order to examine the pre-service teachers' attitudes towards teaching profession and their sense of efficacy beliefs. The observation form consists of the dimensions of the "attitudes towards teaching profession" and "teacher sense of efficacy beliefs". In this form, the dimension of "attitudes towards the teaching profession" consist of a total of three sub-dimensions as interest for the 
teaching profession, love for the teaching profession, and the desire to do the teaching profession. In addition to this, the dimension of "teacher sense of efficacy beliefs" consists of a total of three sub-dimensions as student engagement, using instructional strategies, and classroom management. These questions were presented to the experts from the fields of educational sciences; as a result of the feedback from these experts, the questions were subjected to pilot application. In the study, the observation form prepared was applied in a group of different pre-service teachers, thus, the dimensions' state of serving the purpose was examined in the form. The observation form was made ready to use after the necessary changes were made on it.

Diary Form. Diaries have the qualification of a document in terms of transferring the experiences of the individuals participating in the study (Glesne, 2011). Examination of documents such as diary is of importance in terms of giving the individual point of view of the author of the document (Merriam, 1998). For this purpose, a log form was prepared in order to examine the attitudes of pre-service teachers towards the teaching profession and their sense of efficacy beliefs. The prepared diary form consists of the dimensions of "attitudes towards teaching profession" and "teacher sense of efficacy beliefs". In this form, the dimension of "attitudes towards the teaching profession" consists of a total of three sub-dimensions as interest for the teaching profession, love for the teaching profession, and the desire to do the teaching profession. In addition, the dimensions of "teacher sense of efficacy beliefs" consist of a total of three sub-dimensions as efficacy for student engagement, efficacy for instructional strategies, and efficacy for classroom management. The questions in the diary were presented to the experts from the fields of educational sciences; as a result of the feedback taken from these experts, the questions were subjected to pilot application. The diary form, developed as a result of the pilot application, was made ready to use by making necessary revisions on it.

\section{Data Analysis}

In this research, data analysis was carried out in two stages; these stages were the "analysis of quantitative data" and the "analysis of qualitative data".

\section{Quantitative Data Analysis}

The data obtained from the research group of the study were saved in the SPSS 22.0 package program for appropriate statistical analysis. In the study, before the statistical analyses of the quantitative data, it was checked whether the data showed normal distribution and there was a significant difference between the distributions of their variances. In this study, due to the fact that the size of the research group was less than 30, it was deemed appropriate to use Shapiro-Wilk test in order to check whether the data shows normal distribution (Howell, 2006). In the study, based on the pre-test results obtained from the "Attitude Towards Teaching Profession Scale" (Wpretest $=.95, p=.48, p>.05$ ) and "Teacher Sense of Efficacy Belief Scale" (Wpretest $=.930, p=.30, p>.05)$ to collect quantitative data and the Shapiro-Wilk test results of the data obtained from the post test results of "Attitude Towards Teaching Profession Scale" (Wposttest $=.90, p=11, p$ $>.05$ ) and "Teachers' Sense of Efficacy Belief Scale" (Wposttest $=.96, p=.77, p>.05$ ) showed that the collected data had a normal distribution (Gall, Gall, \& Borg, 2003). Therefore, it was deemed appropriate to use parametric test statistics in the analyses of the quantitative data (Creswell, 2012). In addition, dependent group comparison was made in order to answer the quantitative sub-problems of the study. In the study, dependent samples t-test was used in intergroup comparisons (Gall, Gall, \& Borg, 2003). Descriptive statistics were also used in giving arithmetic mean and standard deviation of the scores obtained from the research group (Shavelson, 2012).

\section{Qualitative Data Analysis}

In the study, before beginning to analyse the qualitative data, firstly the data collected from the pre-service teachers were transferred to computer by the researcher. All qualitative data recorded in the Microsoft Office (MS) Word 2007 package programme were classified separately according to the date and type (observation, interview, and diary). In the study, a list of codes based on the relevant literature (Bogdan \& Biklen, 2003; Denzin \& Lincoln, 2005) was established just before the analysis of the qualitative data. In the study, TC code was given for the interview data obtained from the pre-service teachers, OB code was given for the observation data, and LD code was assigned for the diary data. Content analysis was used in the analysis of the qualitative data obtained in the study (Berg \& Lune, 2011; Miles \& Huberman, 1994). In the content analysis, the data similar to each other were brought together around specific concepts and themes and interpreted in a way that the reader could understand (Patton, 2002). It is aimed to reach more in-depth and more themes with content analysis method rather than an analysis based on predetermined themes according to the results of the study (Miles \& Huberman, 1994). Qualitative data collected for the content analysis were coded twice without interruption and four to five times intermittently by the researcher. The qualitative data set was read 
continuously by the researcher and draft encodings were made on the data output. In this way, draft encodings were made several times. Thus, the consistency of the coding was tried to be ensured comparing the draft encodings made several times. Later, the actual coding process was started after the draft coding and here the themes, where codes can create meaningful patterns, were reached (Auerbach \& Silverstein, 2003). After carrying out studies on trustworthiness and credibility of the qualitative data analysed and the themes reached, the study ended with the stages of data description and reporting.

\section{Trustworthiness and the Credibility of Qualitative Data}

It is very important to provide trustworthiness and credibility for the data collected in qualitative research (Denzin \& Lincoln, 2005). Therefore, it is of great importance to take measures regarding trustworthiness and credibility in the collection of the research data (Bogdan \& Biklen, 2003). In order to ensure the credibility of the data obtained in this qualitative research, the techniques such as diversity, depth-focused data analysis, ensuring long-term interaction, and participation confirmation were used (Erlandson, Harris, Skipper, \& Allen, 1993). The diversity used in the study requires researchers to use multiple and different data sources to develop conceptual categories (Creswell, 2013). Researchers tried to reveal different perspectives of facts and events in various ways through diversification (Patton, 2002). At the same time, in order to understand the role and contribution of teaching practices on pre-service teachers, the researchers spent a long period of time in the field and tried to establish a trust relationship with the stakeholders. Indeed, a researcher who spent a long time in the field can reveal the events, facts, situations, and comments from the perspective of the participants (Glesne, 2011). In this way, researchers were able to collect more depth-oriented data by spending a long time in the field. Also, there is great benefit in the confirmation of the results obtained from the research, and the results and comments that the researcher reach related to them with the data sources (participants) (Yıldırım \& Şimşek, 2008). For this purpose, the researchers gathered the data they collected and presented them to the participants' opinions and asked the pre-service teachers to give their opinion on their accuracy. In this process, however, the researchers also made it possible for the participants to remove their opinions from the data set or add new ones to it.

Detailed descriptions were used in order to ensure the transferability of research findings (Patton, 2002). Credibility of findings in the qualitative research depend on the sufficient description of the data obtained (Bogdan \& Biklen, 2003). As a matter of fact, detailed description is the expression of raw data to the reader without adding comments in a structured way according to the concepts and themes emerging (Yıldırım \& Şimşek, 2008). For this reason, the findings obtained in the research were transferred without any comment and direct quotations were frequently used by the researchers.

\section{Results}

In this part of the research, the findings obtained by analysing the data, which were collected in order to solve both the quantitative and qualitative problems of research were given. For this reason, the findings obtained in the research were given under the headings of "quantitative findings" and "qualitative findings".

\section{Quantitative Findings}

Quantitative findings obtained in the study were examined under the titles of the "attitude towards teaching profession" and "teacher sense of efficacy beliefs".

\section{Attitude towards Teaching Profession}

In the study, in order to be able to compare the pretest and posttest scores of the pre-service teachers obtained from the attitude towards the teaching profession scale, the dependent samples t-test was used (see Table 2).

\section{Table 2.}

Comparison of Pretest and Posttest Scores of Attitude towards Teaching Profession

\begin{tabular}{ccccccc}
\hline $\mathrm{n}$ & Test & $\mathrm{M}$ & $\mathrm{SD}$ & $\mathrm{df}$ & $\mathrm{t}$ & $\mathrm{p}$ \\
\hline & Pre-test & 116.64 & 11.75 & & & \\
14 & Post-test & 128.35 & 7.11 & 13 & -3.22 & $.01^{*}$ \\
\hline
\end{tabular}

Note. ${ }^{*} p<.05$

Looking at Table 2, it was concluded that there was a statistically significant difference between the pretest and posttest scores of pre-service teachers for the attitude towards teaching profession $(t(13)=-3.22, p<.05)$. 
This finding obtained demonstrated that teaching practices were effective in the development of pre-service teachers' attitude towards teaching profession.

Teacher Sense of Efficacy Belief

In the study, in order to be able to compare the pretest and posttest scores of pre-service teachers on sense of efficacy belief scale, t-test was used (see Table 3).

Table 3

Comparison of Pretest and Posttest Scores of Teacher Sense of Efficacy Belief

\begin{tabular}{|c|c|c|c|c|c|c|c|}
\hline Sub-scale & $\mathrm{n}$ & Test & $M$ & SD & $\mathrm{df}$ & $\mathrm{t}$ & $p$ \\
\hline \multirow[t]{2}{*}{ Student Engagement } & & Pre-test & 54.92 & 8.52 & & & \\
\hline & 14 & Post-test & 56.42 & 8.45 & 13 & -.87 & $.39 *$ \\
\hline \multirow[t]{2}{*}{ Instructional Strategies } & & Pre-test & 53.50 & 10.42 & & & \\
\hline & 14 & Post-test & 57.78 & 9.30 & 13 & -1.81 & $.09 *$ \\
\hline \multirow[t]{2}{*}{ Classroom Management } & & Pre-test & 56.85 & 10.00 & & & \\
\hline & 14 & Post-test & 57.14 & 8.89 & 13 & -.11 & $.92 *$ \\
\hline
\end{tabular}

Note. $* p>.05$

Table 3 revealed that there was not a statistically significant difference between the pretest and posttest scores of the pre-service teachers regarding the sense of efficacy belief for student engagement $(t(13)=-.87, p$ $>.05)$, the sense of efficacy belief for instructional strategies $(t(13)=-1.81, p>.05)$, and the sense of efficacy belief for classroom management $(t(13)=-.11, p>.05)$. The finding obtained showed that the teaching practices were not effective in the development of sense of efficacy belief of the pre-service teachers. Although the teaching practices created no significant effect on pre-service teachers' sense of efficacy beliefs, they were seen to develop their efficacy beliefs when arithmetic means were compared.

\section{Qualitative Findings}

The qualitative findings obtained in the study were conceptualised under the main themes entitled as "attitude towards the teaching profession" and "teachers' sense of efficacy belief".

\section{Attitude towards Teaching Profession}

In the study, the findings related to pre-service teachers' attitude towards the teaching profession were conceptualised under three sub-themes (see Table 4).

Table 4.

Attitude towards Teaching Profession

\begin{tabular}{|c|c|c|}
\hline Main Theme & Sub-Themes & Qualitative Data Code \\
\hline \multirow{3}{*}{$\begin{array}{l}\text { Attitude } \\
\text { towards } \\
\text { teaching } \\
\text { profession }\end{array}$} & $\begin{array}{l}\text { Interest in the teaching } \\
\text { profession }\end{array}$ & $\begin{array}{l}\text { TC-1, TC }-3, \text { TC }-4 \text {, TC }-5 \text {, TC }-6, \text { TC-7, TC-8, TC-10, TC-11, TC -13, } \\
\text { TC-14, LD-1, LD-2, LD-3, LD-5, LD-6, LD-7, LD-9, LD-10, LD-11, LD- } \\
\text { 12, LD-13, OB-2, OB-3 }\end{array}$ \\
\hline & $\begin{array}{l}\text { Love for the teaching } \\
\text { profession }\end{array}$ & $\begin{array}{l}\text { TC }-1 \text {, TC }-2 \text {, TC }-3 \text {, TC }-4 \text {, TC }-6 \text {, TC }-7 \text {, TC }-8 \text {, TC }-9 \text {, TC }-10 \text {, TC }-12 \text {, } \\
\text { TC }-13 \text {, TC-14, LD-1, LD-2, LD-3, LD-4, LD-5, LD-6, LD-8, LD-9, LD- } \\
\text { 10, LD-11, LD-12, LD-13, OB-2 }\end{array}$ \\
\hline & $\begin{array}{l}\text { Desire to do the teaching } \\
\text { profession }\end{array}$ & $\begin{array}{l}\text { TC-1, TC-3, TC-4, TC-5, TC-6, TC-7 TC-8, TC-10, TC-13, LD -2, LD-4, } \\
\text { LD-5, LD-6, LD-7, LD-9, LD-10, LD-12, LD-14, OB-3 }\end{array}$ \\
\hline
\end{tabular}

When looked at Table 4, it was observed that the attitudes of pre-service teachers towards the teaching profession were examined under three sub-themes. These sub-themes were determined as "interest in the teaching profession", "love for the teaching profession", and "desire to do the teaching profession". In the study, the first sub-theme was "interest in the teaching profession", so it was concluded that the pre-service teachers' interest in the profession increased at the end of the teaching practices.

I can say that I was not much interested in teaching profession before going to school for an internship [teaching practices]. In other words, I took a step for this profession, but frankly I didn't think it was a profession that attracted my attention very much. My interest in this profession has really increased with teaching practices (TC-8).

Of course, I had an interest in this profession before, but my interest increased with teaching practices. In these practices, I believed that this profession was right for me (TC -3).

[...] My interest in the teaching profession has improved more through teaching practices (GN-11). 
Pre-service teachers began to talk more about the teaching profession. It was seen in their speeches that there were sentences about their interest in teaching (OB-3).

I think the teaching profession is very suitable for me. This profession has begun to attract my attention more. I am very excited to think that I will do this profession (TC -13).

Looking at the excerpts given above, it was understood that the pre-service teachers' interest in the teaching profession increased. In the study, it was observed that while some pre-service teachers' interest in the profession was low before the teaching practices, their interest increased with these practices. Also, in the study, it was concluded that the pre-service teachers' love towards the profession as well as their interest showed improvement through teaching practices.

I love the teaching profession very much. My love for this profession has increased even more thanks to teaching practices (TC-7).

The teaching profession has started to seem very attractive to me. Of course, I can never ignore the role of teaching practices in this. Thanks to these practices, I have started to love the teaching profession even more (LD-6).

I didn't really have much love for the teaching profession before. However, my love for this profession has improved more through teaching practices (TC-9).

[...] It was observed that pre-service teachers loved the teaching profession more when they went to schools for practices. It was seen that pre-service teachers expressed that they were very happy on the days when they went to schools for practice (OB-2).

As a matter of fact, I can't say that I love this profession very much before teaching practices. However, thanks to these applications I have understood that I really like the teaching profession (TC1).

Looking at the views above, it was understood that pre-service teachers started to love the teaching profession thanks to their teaching practices. In the study, it was seen that while some pre-service teachers' prior love for the profession was low before teaching practices, it increased with these applications. In addition, it was concluded that the pre-service teachers had the desire to do the profession in the future through teaching practices.

After my teaching practices, my desire to do the teaching profession in the future has increased even more. At first, I thought, after graduation, maybe I would not do this job, however, after the teaching practices; my desire to do this profession has increased (TC-5).

In the future, I want to do the teaching profession very much. [...] I think this profession is really suitable for me (LD-12).

I definitely want to do this profession in the future. I look forward to doing this profession as soon as possible (TC-4).

I want to perform the teaching profession very much. This profession is very suitable for my qualifications. I want to have my own students and I want to do the teaching profession very much (TC-6).

As shown in the quotations above, it was understood that the pre-service teachers' desire to do the teaching profession in the future improved. In the research, it was concluded that the pre-service teachers wanted to begin the teaching profession as soon as possible and to perform this profession in the near future.

Teacher Sense of Efficacy Belief

In the study, the findings related to pre-service teachers' sense of efficacy belief were conceptualised under three sub-themes (see Table 5).

Table 5.

Teacher Sense of Efficacy Belief

\begin{tabular}{lcc}
\hline Main Theme & Sub-Themes & Qualitative Data Code \\
\hline \multirow{4}{*}{$\begin{array}{l}\text { Teacher } \\
\text { sense }\end{array}$} & $\begin{array}{c}\text { Efficacy for student } \\
\text { engagement }\end{array}$ & TC-2, TC-3, TC-5, TC-6, TC-8, TC-9, TC-11, TC-12, TC-14, LD-2, LD- \\
efficacy & Efficacy for instructional & TC-1, TC-2, TC-4, TC-6, TC-7, TC-9, TC-10, TC-11, TC-12, TC-14, LD- \\
belief & strategies & 2, LD-4, LD-6, LD-7, LD-8, LD-11, LD-14, OB-1, OB-2, OB-3 \\
& Efficacy for classroom & TC-1, TC-2, TC-3, TC-4, TC-6, TC-8, TC-9, TC-10, TC-11, TC-13, TC- \\
& management & 14, LD-1, LD-2, LD-5, LD-7, LD-9, LD-12, LD-14, OB-1, OB-3 \\
\hline
\end{tabular}


Table 5 shows that pre-service teachers' sense of efficacy belief was examined under three sub-themes. These sub-themes were determined to be "sense of efficacy for student engagement", "sense of efficacy for instructional strategies", and "sense of efficacy for classroom management". In the study, the first sub-theme that emerged was "sense of efficacy for student engagement". At the end of the teaching practice, it was concluded that "sense of efficacy belief for student engagement" of the pre-service teachers showed no improvement.

I don't know the ways about how to ensure the participation of the students. In other words, I don't feel competent in ensuring the students' participation in the lesson. No matter what I do, I fail in having my students participate in the lesson effectively (TC-2).

Frankly, I do not consider myself competent in having students participate in the lesson. All I do in the classroom is to ask questions to students. I cannot make them participate in the class by just asking questions (TC-12).

[...] in particular, I'm aware that only I am speaking in the lesson. The only way that I use for having students participate in class is to ask questions. I think I should improve this (LD-4).

I want students to participate in class effectively. However, I don't know exactly how I'm supposed to do this (TC-14).

In the study, it was observed that pre-service teachers stated that they were not competent enough in ensuring student engagement. While the pre-service teachers stated that they were not competent to provide student engagement, they stated that the only way they used to ensure student engagement in the classroom was the question-answer technique. This finding that emerged in the research was also reflected in some observation results.

It was observed that the pre-service teachers used the question-answer technique to ensure the student engagement in the class. It was observed that the pre-service teacher using this technique was not competent in ensuring student engagement (OB-1).

It was observed that the pre-service teacher applied the question-answer technique in order to ensure the student engagement in the course. However, it was observed that student engagement remained very limited with this technique (OB-2).

Looking at the quotations regarding the observation record, it was understood that pre-service teachers were competent in providing student engagement. It was determined that pre-service teachers only used the question-answer technique to ensure student engagement. Also, the pre-service teachers included in the study stated that they experienced inefficacy to ensure student engagement in the classroom by providing student motivation.

Essentially, I think students have motivation problems in the classroom. Therefore, they are reluctant to attend the class. [...] I have no idea how to ensure students' engagement effectively in the classroom by motivating them (TC-11).

[...] I think that students do not have enough motivation to attend the class. I really don't know how to motivate them to attend class (LD-13).

I'm trying to motivate the students by only mentioning that the subject will be asked in the exams. However, I don't think that works very much (TC-3).

Looking at the opinions expressed by the pre-service teachers, it was understood that they felt inefficient in providing student motivation. However, it was concluded that pre-service teachers also experienced incompetency in ensuring the unsuccessful students to understand the course better.

It is easy to teach the course to the successful students, in other words, it is very easy to ensure the participation of the successful students in the class. The main problem I'm having is ensuring the participation of failing students. [...] Considering that most of the classroom consists of unsuccessful students, I can say that I really have a problem in ensuring the participation of these students (TC-6). The course is very monotonous. Generally speaking, I can say that the course is carried out with a small number of students. Very few students participate in the class (LD-5).

I really feel incompetent in ensuring the participation of the failing students because, in order for a course to be effective, all students must be actively involved in the course. I can't achieve it (TC-9).

Pre-service teacher teaches a lesson in the class with a few students participating. He is directing the teaching-learning process with four students sitting in the front row in the way of question-answer (OB-3).

When the above quotations were examined, it was determined that while the pre-service teachers experienced no problems in ensuring the engagement of successful students, they experienced problems 
especially in ensuring the participation of the failing students in the classroom. In this sense, it could be suggested that teaching practices did not improve the sense of efficacy belief of pre-service teachers. On the other hand, it was concluded that pre-service teachers had incompetency in using instructional strategies in the study.

In the classroom, I usually apply the direct instruction method. Apart from that, I do not apply a different teaching method (TC-7).

The pre-service teacher mostly uses the direct instruction method. He only explains the subject and checks whether the students understand the subject through the question (OB-1).

Frankly, I don't feel myself competent in implementing instructional strategies. There are few strategies I know. Apart from that, I do not apply different methods (TC-9).

When the above quotations were examined, it was observed that pre-service teachers were not competent in applying different instructional strategies in the classroom. In addition, the pre-service teachers expressed that they also felt incompetent in creating appropriate learning environments for students.

I don't think the classroom environment is suitable for students to learn effectively. However, I have no idea how to make the class a suitable learning environment (TC-10).

The pre-service teacher conducted teaching activities before making any changes in the classroom environment (OB-2).

I'm not doing any changes in the class environment before the lesson. The existing learning environment is not sufficient for students, but I think I can't do anything else (LD-8).

While the pre-service teachers expressed their inability to create an appropriate learning environment within the classroom, they stated that they had difficulty in finding suitable answers to some questions from the students.

Sometimes students may ask challenging questions. Frankly, I'm surprised by these questions. I can't answer (TC-12).

Today a student asked me a really challenging question about a topic that I was teaching. I had a hard time answering the student. I said I would answer this question next week (LD-2).

I'm having trouble answering some questions of the students. [This kind of questions] are indeed compelling (TC-1).

The pre-service teacher saw someone raising his or her hand. She let the student ask a question. When the student asked his question, the pre-service teacher said that she did not know the answer of that question (OB-3).

When the quotations given were examined, it was understood that pre-service teachers stated that some of the questions asked by the students were challenging and they had problem finding suitable answers to these questions. However, the pre-service teachers stated that they felt incompetent in creating alternative explanations and examples when students were confused or unable to understand a topic.

Sometimes while teaching a topic, I see that the students cannot understand the subject. However, I find it hard to explain it to the students in a different format. I find it difficult to find different explanations (TC-14).

When students do not understand the subject, they want different examples from me. Although I give different examples, they aren't satisfied with these examples very much. I've got to do something very different about this (LD-7).

When looked at the statements above, it was found that the pre-service teachers were insufficient to provide alternative explanations and examples in order to make students understand the subject they did not understand. It was concluded that pre-service teachers were not competent to provide different explanations and examples in order to make students understand the subject they did not understand. In the study, the last sub-theme that emerged was "sense of efficacy for classroom management". At the end of the teaching practices, it was understood that pre-service teachers' sense of efficacy for classroom management did not show any improvement.

I do not feel competent in activities carried out in the classroom in a regular way. I mean, I can't say that I'm feeling very competent in class management (TC-8).

I can't do anything against students who display improper behaviours in class (LD-12).

I, personally, cannot direct a student who misbehaves in class to the lesson. I have no idea about how to do it (TC-13).

[...] A pre-service teacher warned a student making noise in the classroom. After remaining quiet for 2-3 minutes, the student started to speak again. The pre-service teacher warned the student again. 
However, this time the student continued talking with his or her friend without paying any attention to this warning (OB-1).

For example, there is a student in the class. He does not care about anyone. He sabotaged me many times while I was lecturing. However, I couldn't do anything to such students (LD-1).

When the quotations were examined, it was seen that the pre-service teachers felt themselves incompetent in preventing undesired student behaviours in class. In other words, the pre-service teachers suggested that they experienced incompetency in classroom management. Also, the strategies used by the preservice teachers to control undesirable behaviours in the classroom showed that they experienced inadequate classroom management.

I mean, I don't know how to control a student with a negative attitude. Probably, the only thing I can do is warning verbally (TC-6).

I use [verbal] warning to control the student who is displaying undesirable behaviour in the classroom. You know, I tell him/her that I will complain to the headmaster of the school (TC-14).

When I see a student who displays a negative attitude in the classroom, I only get angry with him or her (LD-5).

For example, there is a student in the classroom. He is controlling the Smart Board by his telephone. I know he is doing it. I can't do anything about it. Going next to him I told him to turn off the phone but he turned his head, he didn't listen. I ignored it once, but he kept doing it (TC-9).

While writing on the board, pre-service teacher turned around to warn a student who talks too much. The student responded to the pre-service teacher in a scolding way. Upon this, the pre-service teacher acting as if nothing had happened continued writing on the Blackboard. There was laughter in the classroom (OB-3).

When the above quotations were examined, it was observed that pre-service teachers had difficulty in controlling students displaying negative behaviours in the classroom. In the study, it was understood that the strategies used by pre-service teachers to control students having negative behaviours in the classroom were generally ignoring or verbally warning. In addition, the pre-service teachers expressed that they felt incompetent in ensuring the students in compliance with the classroom rules.

From time to time, I remind the class rules to students. But, I see they don't obey them. I can't do

anything about it (TC-4).

[...] I can't get the students to obey to the classroom rules (LD-7).

Students, unfortunately, have no consciousness of following class rules. I really don't feel competent

in ensuring this (TC-10).

As can be seen, while the pre-service teachers stated that students did not comply with the classroom rules, they also implied that they did not know how to ensure their compliance with these rules. The pre-service teachers suggested that they experienced feeling of incompetency by expressing that they had problems in terms of students' compliance with the classroom rules.

\section{Discussion, Conclusion and Implications}

In the present study, the effect of teaching practices on pre-service teachers' attitude towards the profession and sense of efficacy beliefs were examined. In the study, exploratory sequential mixed methods design was used, and the process involved collecting quantitative data and then supporting quantitative findings with qualitative data.

According to the first finding in the study, it was concluded that teaching practices had a statistically significant effect on the attitude of pre-service teachers towards the profession. This finding showed that teaching practices were effective in developing pre-service teachers' attitude towards the profession. In addition, in the qualitative data obtained, it was understood that the teaching practices had a significant contribution to the development of positive attitude towards the profession. In the research, the pre-service teachers expressed that their interest and love towards the profession increased with teaching practices and their desire to do the profession in the future also developed. In the previous research, it was seen that while pre-service teachers receiving pedagogical formation training had positive attitude towards the teaching profession (Eraslan \& Çakıcı, 2011; Yenice \& Alpak-Tunç, 2016), they were also understood to love the profession (Dikmen \& Tuncer, 2018), had an interest in it (Özkan, 2012), showed commitment to it (Gülşen \& Seyratlı, 2014; Özkan, 2012), and had a tendency to perform it in the future (Gülşen \& Seyratlı, 2014). Preservice teachers' positive attitude towards the teaching profession will enable them to be more effective in 
performing this profession (Tarman, 2012). The success of pre-service teachers depends on their love and willingness to perform this profession (Aydın \& Sağlam, 2012). As a matter of fact, it is unlikely that pre-service teachers can fulfill the teaching profession effectively and efficiently without having positive attitude (Çeliköz \& Çetin, 2004). In this respect, it can be said that teaching practices have a very important place in pre-service teachers' gaining positive attitude towards the profession. Teaching practices, which have a very important place in the education of pre-service teachers (Ben-Peretz, 2001), contribute positively to their attitude towards the profession (Karasu-Avcl \& Ünal-ibret, 2016) besides provide pre-service teachers with teaching skills (Hacıömeroğlu \& Şahin, 2011; Akpınar, Çolak, \& Yiğit, 2012), and competencies (Sarıçoban, 2008; Tarman, 2012). While these practices make pre-service teachers' knowledge more permanent, they also create important changes in their attitude towards the profession (Demirtaş, Cömert, \& Özer, 2011) because if preservice teachers develop positive attitude towards the teaching profession, they perform the profession more effectively and efficiently (Çeliköz \& Çetin, 2004). However, it is seen that the research on the effect of teaching practices on pre-service teachers' attitude towards profession reveals different results. While some studies on this subject show that teaching practices positively improve pre-service teachers' attitude towards the profession (Kılıç, 2004; Şişman \& Acat, 2003), some studies show that these practices adversely affect their attitude towards the profession (Koç \& Demirel, 1999; Toprakçı, 2003). However, it is aimed to make positive contributions with these practices to pre-service teachers' attitude towards profession (Karasu-Avcı \& Ünalibret, 2016). From this perspective, it is thought that the different experiences of pre-service teachers in schools may be effective in these results presented by the research literature. Indeed, the interaction of preservice teachers with students and teachers in schools may affect their feelings and thoughts positively or negatively, and may cause them to get closer to or be away from the teaching profession (Oğuz, 2004). However, it is thought that whether or not encountered with problems in these applications can affect the attitude of pre-service teachers towards the profession positively or negatively (Azar, 2003; İnan \& Özgen, 2008). Teaching practices, which carry out an important function (Aslan \& Sağlam, 2018), should be regulated in order for pre-service teachers not to experience negative experiences and gain positive attitude towards the profession (Oğuz, 2004). In this sense, it is very important to realise these practices, which have an important role in the formation of positive opinions of pre-service teachers (Gökçe \& Demirhan, 2005), under the guidance of leading teachers in the profession and in schools with appropriate conditions.

According to another finding obtained in the study, it was concluded that teaching practices did not have a statistically significant effect on the sense of efficacy belief of pre-service teachers. The finding obtained showed that teaching practices were not effective in developing sense of efficacy belief (student engagement, instructional strategies and classroom management) of pre-service teachers. In addition, it was understood from the qualitative data obtained, the teaching practices did not contribute to the development of sense of efficacy belief of pre-service teachers. In the study, the pre-service teachers stated that there was no difference in sense of efficacy belief related to student engagement, instructional strategies, and classroom management through teaching practices. Previous research reports that the sense of efficacy of pre-service teachers, who are receiving pedagogical formation training, is in a higher level (Bakaç \& Özen, 2017; Dadandı, Kalyon, \& Yazıcı, 2016; Elkatmış, Demirbaş, \& Ertuğrul, 2013). However, the qualitative research literature demonstrates different results. The research literature provides inconsistent results on the sense of efficacy of pre-service teachers (student engagement, instructional strategies, and classroom management) (Ercan-Özaydın, Çavaş, \& Cansever, 2017; Şahin-Taşkın \& Hacıömeroğlu, 2010). In the study carried out by Ercan-Özaydın, Çavaş, and Cansever (2017), it was seen that pre-service teachers felt competent regarding student engagement, instructional strategies, and classroom management. Similarly, in other studies, the pre-service teachers, who are receiving pedagogical formation training, were determined to feel competent in terms of teaching-learning process (Akyıldız, 2017; Yalçın \& Akay, 2015) and measurement and evaluation (Erdoğdu \& Kurt, 2012; Yalçın \& Akay, 2015). On the contrary, in a study conducted by Taşkın and Hacıömeroğlu (2010), it was found that preservice teachers did not feel competent in relation to student engagement, instructional strategies, and classroom management. However, it is important for pre-service teachers to be able to engage students in the classroom, use appropriate instructional strategies, and to have proficiency in classroom management to create an effective teaching-learning process (Tschanen-Moran, Woolfolk-Hoy, \& Hoy, 1998). In other words, it is not possible for pre-service teachers who do not have the necessary competencies in this issue to construct an effective teaching and learning process (Tschanen-Moran \& Hoy, 2001). The data obtained in the study revealed that the teaching practices were inadequate to improve the sense of efficacy beliefs of pre-service teachers about student engagement, instructional strategies, and classroom management. From this perspective, it is possible to say that teaching practices do not make enough contribution to the pre-service 
teachers' sense of efficacy belief. However, the applications that pre-service teachers realise in schools are of great importance for them to improve their sense of efficacy belief (Bayrakdar, Vural-Batık, \& Barut, 2016). Teaching practices, which are thought to have an important place in developing teacher's sense of efficacy belief (Sağır, Bilen, \& Ercan, 2014), help pre-service teachers see their strengths and weaknesses (TschanenMoran, Hoy, \& Woolfolk-Hoy, 1998). At the same time, these practices provide direct experiences to preservice teachers and contribute to the development of their sense of efficacy belief (Tschanen-Moran \& Hoy, 2001). After teaching practice, pre-service teachers are expected to gain experience in organising students in the classroom, communicating with them and actively including them in the teaching-learning process (Aktağ, 2011). However, the research literature shows that teaching practices do not have a significant effect on the sense of efficacy belief of pre-service teachers (Aktağ, 2011; Sağır, Bilen, \& Ercan, 2014). In addition, the related literature also reports that teaching practices are not shown as effective courses by pre-service teachers (Görgen, Çokçalışkan, \& Korkut, 2012). Therefore, it can be said that the research literature supports the findings of this study. This result reveals that teaching practices are inadequate in developing sense of efficacy beliefs of pre-service teachers. It is thought that some reasons may be effective in the emergence of the finding obtained. The following reasons can be said to be effective in the emergence of the finding:, the inadequacy of the duration of teaching practices (Özkılıç, Bilgin, \& Kartal, 2008), lack of adequate conditions of practice schools, lack of competent mentor teachers (Aslan \& Sağlam, 2018), lack of competent instructors (Topkaya, Tokcan, \& Kara, 2012), high number of pre-service teachers per instructor (Azar, 2003), lack of opportunity for pre-service teachers to develop themselves (Çelikten, Şanal, \& Yeni, 2005), and lack of coordination between faculty and practice school (Aydın, Selçuk, \& Yeşilyurt, 2007). Therefore, teaching practices need to be regulated in a way that pre-service teachers develop adequate level of sense of efficacy beliefs. It is because HEC has revised its curricula and has extended its teaching practice to two semesters for all departments (HEC, 2018). Along with that, the MoNE has limited the number of pre-service teachers per teacher in teaching practices to a maximum of eight (MoNE, 2018). When looked at these regulations, it is understood that it is aimed to train pre-service teachers more effectively. It can be argued that the fact that HEC (2018) extended its teaching practice to two semesters for each department has allowed the pre-service teachers to practice for longer periods of time and that with the amendment it has made, MoNE (2018) tries to make interaction between instructor, mentor and pre-service teachers more efficient. Although the regulations of HEC (2018) and MoNE (2018) regarding their teaching practices are considered positive, it seems that the system continues to have some problems. For example, the fact that the schools of practice do not have appropriate conditions, mentor teachers do not have the necessary competences (Aslan \& Sağlam, 2018), the inadequate teaching staff to provide guidance and education faculties' being not selective in the selection of mentor teachers (Topkaya, Tokcan, \& Kara, 2011) may be shown amongst these problems. Therefore, it can be argued that these problems reduce the expected efficiency from teaching practices. In this context, it may be said that the focus should be on a holistic approach to teaching practices rather than making partial changes over applications.

As a result, while it was seen in the study that teaching practices are effective in developing pre-service teachers' attitude towards the profession, it was understood that these practices were not effective in developing their sense of efficacy beliefs. Therefore, it can be said that increasing the duration of teaching practices is very important. In this way, it is expected that both pre-service teachers will spend more time in schools and improve their attitude towards the profession and they will be able to improve the sense of efficacy beliefs by having the opportunity to practice more. It can also be stated that special attention should be given to the choice of practice schools. As a matter of fact, it is not possible for pre-service teachers to develop positive attitude towards the profession or to develop the sense of efficacy beliefs in schools which do not have appropriate conditions. Similarly, it is recommended that lecturers and mentors who do not have the necessary competency should not be preferred for these applications. From this point of view, it is very important to especially select mentors who have received teaching education and have high level of sense of efficacy beliefs in their profession. For this purpose, faculty of education should show the required sensitivity in the selection of instructor and the National Education Directorates should show the required sensitivity in the selection of mentors and practice schools. At the same time, it is of great importance to increase the coordination between practice schools and faculties of education and to try to solve the problems that arise in practice by the coordination of these institutions. Finally, it is required to make necessary regulations by considering teaching practices as a holistic approach rather than a partial approach. 


\section{TÜRKÇE SÜRÜM}

\section{Giriş}

Eğitim sisteminin en önemli öğesinin öğretmen olduğu gerçeğinden hareketle (Koç \& Demirel, 1999), öğretmenin hem sistemden etkilenen hem de sistemi etkileyen bir unsur olduğu söylenebilir (Aslan \& Sağlam, 2017). Öğretmenler istenilen nitelikte bireylerin yetiştirilmesinde sistem içinde köşe taşı olarak yer alan bireylerdir (Özay-Köse, 2014). Toplumun kalkınması, gelişmesi ve nitelikli insan gücünün yetiştirilmesinde öğretmen yadsınamaz bir role sahip bulunmaktadır (Aslan \& Sağlam, 2018). Bu açıdan, eğitimde istenilen hedeflere ulaşmada öğretmenlerin iyi bir biçimde yetiştirilmesi gerektiği dile getirilebilir (Kana, 2014). Dolayısıyla, eğitim sisteminin çağın gerektirdiği hedeflere ulaşabilmesi ve eğitimin kaliteli bir hale gelmesi için öğretmen eğitimi oldukça önemli bir yer teşkil etmektedir (Sağlam \& Kürüm, 2005). Zira, öğretmen eğitimine gerekli önemin verilmemesi niteliksiz öğretmenlerin sisteme girmesine sebep olacağı; bunun da eğitim sistemini olumsuz bir biçimde etkileyebileceği ifade edilebilir (Aslan \& Sağlam, 2018). Çünkü, nitelikli öğretmenler yetiştirmeden eğitim sisteminde yapılan değişiklikler istenen etkiyi oluşturamazlar (Kana, 2014). Bu bağlamda, eğitim reformlarının önemli bir bölümünü öğretmen eğitiminin oluşturduğu (Ekinci \& TicanBaşaran, 2015) ve öğretmen eğitiminin eğitim sisteminin niteliğini belirleyen unsurların başında geldiği söylenebilir (Oğuz, 2004). Eğitim sisteminin niteliğini geliştirmenin odağını öğretmenin oluşturması, dikkatleri öğretmen yetiştirme programlarına çekmektedir (Ekinci \& Tican-Başaran, 2015). Nitekim, öğretmen adaylarının hizmet öncesinde yetiştirilmesinde işe koşulan programların niteliği öğretmenlerin niteliğini de yakından etkilemektedir (Görgen, Çokçalışkan \& Korkut, 2012). Bu sebeple, öğretmenlerin gerçekleştirdikleri eğitim hizmetlerinin niteliğini belirleyen değişkenlerin başında, hizmet öncesinde aldıkları eğitimin olduğu ileri sürülebilir (Sağır, Bilen \& Ercan, 2014).

Eğitim sisteminde öğretmenlerin birtakım niteliklere sahip olmaları beklenmektedir (Milli Eğitim Bakanlığı [MEB], 2017). Bu açıdan, öğretmenlerin belirli niteliklere sahip olabilmeleri için iyi bir hizmet öncesi eğitim sürecinden geçirilmeleri gerekmektedir (Aslan \& Sağlam, 2018). Hizmet öncesinde gerçekleştirilen eğitimin en önemli boyutunu ise öğretmenlik uygulamaları teşkil etmektedir (Koç \& Demirel, 1999). Bu uygulamalar, öğretmen adaylarının kuramsal açıdan öğrendiklerini uygulamaya koyma fırsatı veren oldukça önemli bir ders niteliğindedir (Aslan \& Sağlam, 2017). Hizmet öncesinde aldıkları öğretmenlik uygulaması dersinin öğretmen adaylarına sahip oldukları kuramsal bilgileri uygulamaya koyma fırsatı sunması sebebiyle, bu dersin öğretmenlik becerilerinin gelişmesinde önemli bir yere sahip olduğu söylenebilir (Sağır, Bilen \& Ercan, 2014). Öğretmen adaylarının hizmet öncesinde kazanmış oldukları kuramsal bilgileri uygulamaya dönüştürme amacıyla işe koşulan öğretmenlik uygulaması dersi (Özkan, Albayrak \& Berber, 2005), öğretmen adaylarının eksikliklerini belirlemede oldukça önemli bir yere sahip bulunmaktadır (Kana, 2014). Zira, öğretmen adaylarının sahip oldukları kuramsal bilgileri sınıf içinde etkili ve verimli bir biçimde kullanabilmeleri, hizmet öncesinde yeterli uygulama fırsatı bulabilmeleri ile mümkün gözükmektedir (Harmandar, Bayrakçeken, Kıncal, Büyükkasap \& Kızılkaya, 2000).

Öğretmen adaylarının okullarda gerçekleştirdikleri uygulamalar, öğretmenlik mesleği ile ilgili alan bilgisi, genel kültür ve pedagojik formasyon bilgisiyle ilgili becerilerini geliştirebilmeleri açısından büyük bir önem taşımaktadır (Rıza \& Hamurcu, 2000). Öğretmenlik uygulamaları, öğretmen adaylarının mesleğin gerektirdiği yeterlik ve sorumlulukları kazanmalarında önemli bir yardımcı niteliğindedir (Koç \& Demirel, 1999). Bu maksatla, Yükseköğretim Kurulu (YÖK) öğretmen eğitiminde kuramsal bilgilerin uygulamaya aktarılmasını sağlamak için çeşitli çalışmalar gerçekleştirmiş olup (Görgen, Çokçalışkan \& Korkut, 2012), bu çalışmalardan birini de fakülte-okul işbirliğini artırmak için öğretmen eğitimi programlarına eklediği öğretmenlik uygulaması dersi oluşturmuştur (YÖK, 1998). Bu ders, YÖK-Dünya Bankası “Milli Eğitimi Geliştirme Projesi” kapsamında öğretmen adaylarının kazanmış oldukları bilgi ve becerileri sınıf ortamında uygulayarak geliştirebilmeleri için planlanmış olan bir derstir (YÖK, 1998). Öğretmenlik uygulaması dersi, öğretmen adaylarına hizmet öncesinde kazandıkları bilgileri sınıflarda uygulama fırsatı ve rehber (uygulama) öğretmenleri/öğretim elemanları ve öğrencilerden geribildirim alma imkânı veren bir uygulama niteliği taşımaktadır (YÖK, 2007). Okullarda gerçekleştirilen bu uygulamaların en önemli amacını ise, öğretmenlik mesleğinin tanıtılması ve rehber öğretmenlerinin öğretmen adaylarının mesleki gelişimine katkıda bulunması teşkil etmektedir (Gökçe \& Demirhan, 2005). Öğretmen eğitiminde önemli bir yere sahip olan öğretmenlik uygulaması dersinin (Aslan \& Sağlam, 2017), aynı zamanda, öğretmen adaylarının mesleğe yönelik tutumunu pozitif yönde artırması (ÖzayKöse, 2014) ve onların mesleki yeterliklerini geliştirmesi beklenmektedir (Eker, 2015; Sağır, Bilen \& Ercan, 2014). Öğretmenlik mesleğine başladıklarında, görevlerini etkili bir biçimde yerine getirebilmeleri için öğretmen 
adaylarının özyeterlik inancı yüksek düzeyde olmalıdır (Tschanen-Moran ve Hoy, 2001). Öğretmen adaylarının özyeterlik inancının oluşmasında en etkili yol olan okullarda gerçekleştirilen öğretmenlik uygulamaları başarıı olursa, bu uygulamalar öğretmen adaylarının kendilerini yeterli hissetmelerine katkıda bulunabilir (Öksüz \& Coşkun, 2012). Çünkü, öğretmen adayları öğretmenlik uygulamaları vasıtasıyla hem güçlü hem de zayıf yönlerini görerek özyeterlik inancını geliştirebilirler (Tschanen-Moran, Woolfolk-Hoy \& Hoy, 1998). Nitekim, öğretmenlik uygulamaları öğretmen adaylarına doğrudan yaşantılar sunan bir niteliğe sahip bulunmaktadır (TschanenMoran \& Hoy, 2001). Bu açıdan, doğrudan yaşantılar sunan bu uygulamaların öğretmen adaylarıın özyeterlik inancının gelişmesine önemli katkılar yapabileceği söylenebilir (Tschanen-Moran, Woolfolk-Hoy \& Hoy, 1998). Bu bağlamda, hizmet öncesi eğitim döneminde alınan öğretmenlik uygulamaları dersi, öğretmen adaylarının özyeterlik inancının geliş̧mesinde en fazla etkiye sahip olan ders olarak nitelendirilebilir (Öksüz \& Coşkun, 2012). Aynı zamanda, öğretmenlik mesleğini icra edecek olan bireylerin bu mesleğin gerekliliklerini daha etkili bir biçimde yerine getirebilmelerinin ön koşullarından bir diğerini de öğretmenlik mesleğine yönelik tutum teşkil etmektedir (Bayrakdar, Vural-Batık \& Barut, 2016). Bireylerin mesleklerine yönelik sahip oldukları tutumun, mesleklerindeki başarılarını olumlu ya da olumsuz yönde etkileyebileceği görüşünden hareketle (Semerci \& Semerci, 2004), öğretmen adaylarının mesleğe başladıklarında görevlerini yerine getirebilmelerinde öğretmenliğe yönelik olumlu tutuma sahip olmalarının oldukça önemli olduğu söylenebilir (Nalçacı \& Sökmen, 2016). Zira, öğretmen adaylarının öğretmenlik mesleğine yönelik olumlu tutum geliştirmeleri, onların bu mesleği icra ederken daha etkili olmalarını sağlayacaktır (Koç \& Demirel, 1999). Öğretmen adaylarının meslekte başarııı olmaları, onların bu mesleği sevmelerine ve isteyerek icra etmelerine bağlıdır (Aydın \& Sağlam, 2012). Öğretmen adaylarının öğretmenlik mesleğine olumlu tutuma sahip olmadan, bu mesleği etkili ve verimli bir biçimde yerine getirebilmeleri pek mümkün gözükmemektedir (Çeliköz \& Çetin, 2004). Bu anlamda, hizmet öncesi eğitim döneminde alınan öğretmenlik uygulamalarının, öğretmen adaylarının mesleğe yönelik olumlu tutum kazanmalarında yadsınamaz bir role sahip olduğu düşünülmektedir (Şişman \& Acat, 2003). Sonuçta, öğretmenlik uygulamaları öğretmen adaylarının mesleğe yönelik olumlu tutum kazanmalarında olduğu kadar (Bayrakdar, Vural-Batık \& Barut, 2016), özyeterlik inancını geliştirmelerinde de önemli bir yere sahip bulunmaktadır (Öksüz \& Coşkun, 2012).

Öğretmenlik uygulamaları öğretmen adaylarının mesleğe yönelik olumlu tutum kazanmalarının yanı sıra, özyeterlik inancını geliştirmelerinde oldukça önemli bir yere sahip olsa da (Ben-Peretz, 2001), bu konuda çok az şey bilinmektedir. Araştırma alanyazını, öğretmenlik uygulamalarının öğretmen adaylarının mesleğe yönelik tutumunu (Kılıç, 2004; Koç \& Demirel, 1999; Şişman \& Acat, 2003; Toprakçı, 2003) ve özyeterlik inancını (Aktağ, 2011; Sağır, Bilen \& Ercan, 2014) geliştirdiğini rapor etse de, bu durum pedagojik formasyon eğitimi alan öğretmen adayları açısından belirsizdir. Türkiye'de ortaöğretim düzeyindeki öğretmen ihtiyacı genel olarak fenedebiyat fakültesi mezunları tarafından karşılanmaktadır. Ancak, pedagojik formasyon eğitiminin bir yıllık kısa bir zaman aralığına sıkıştııııış olması, öğretmen adaylarının gerekli yeterlikleri kazanıp kazanmadıkları konusunda soru işareti oluşturmaktadır. Eğitim fakültesinde öğrenim gören öğretmen adaylarının aksine, pedagojik formasyon eğitimi alan öğretmen adayları bir yıl içerisinde hem eğitim bilimi ile ilgili dersleri almaktalar hem de öğretmenlik uygulamasını icra etmektedirler. Bu durum, ister istemez, pedagojik formasyon eğitiminin nitelikli öğretmen yetiştirme konusundaki yeterliğini de sorgulanır bir duruma getirmektedir. Bu doğrultuda, bu açıklayııı sıralı karma yöntem araştırmasının amacını (Creswell \& Plano-Clark, 2011; Tashakkori \& Teddlie, 1998), öğretmenlik uygulamalarının pedagojik formasyon eğitimi alan öğretmen adaylarının mesleğe yönelik tutum ve özyeterlik inancı üzerindeki etkisi ile rolünü ortaya çıkartmak teşkil etmiştir.

\section{Yöntem}

\section{Araştırma Deseni}

Bu araştırma bir karma yöntem araştırması olup (Tashakkori \& Teddlie, 1998), bu çalışmada karma yöntem araştırma desenlerinden biri olan açıklayııı ardışık desen kullanıımışıı (Creswell \& Plano-Clark, 2011). Açıklayıcı ardışık desenin amacı, araştırma problemine hem verinin toplanması hem de analizi için nicel aşama ile başlayıp, daha sonra nicel sonuçları açıklamak için nitel çalışmanın yürütülmesidir (Creswell, 2012). Gerçekleştirilen bu araştırmada açıklayıı desenin kullanıımasının temel gerekçesini ise, farklı desenlerin farklı güçlü ve zayıf yanları olduğu ve bu farklılılardan yararlanmak için verilerin etkili bir biçimde birleştirilebileceği hususu teşkil etmiştir (Plano-Clark \& Ivankova, 2016). Dolayısıyla, bu araştırmada ilk olarak nicel veriler toplanmış, ardından da nicel bulguların açıklanmasına ve detaylandııımasına yardımcı olması için nitel veriler elde edilmiştir. 


\section{Çalışma Grubu}

Bu araştırmanın çalışma grubunu, 2017-2018 akademik yıııın bahar döneminde Niğde Ömer Halisdemir Üniversitesi, Eğitim Fakültesi, Pedagojik Formasyon Eğitimi Sertifika Programında öğrenim görmekte olan öğretmen adayları $(n=14)$ teşkil etmiştir. Araştırmanın çalışma grubunu teşkil eden öğretmen adayları, aynı zamanda, aynı üniversitenin Fen-Edebiyat Fakültesi Tarih Bölümü 4. sınıfında öğrenim görmektedirler. Araştırmanının çalışma grubunun \%50'sini $(n=7)$ erkek, \%50'sini ise $(n=7)$ kız öğretmen adayları oluşturmuştur. Bunun yanı sıra, araştırmaya katılan öğretmen adaylarının yaş ortalaması 21 'dir (SS = .13).

\section{Prosedür}

Araştırmada, öğretmen adayları toplam 14 hafta boyunca öğretmenlik uygulamaları gerçekleştirmişlerdir. Araştırmadaki bu süreç, YÖK tarafından belirlenen programa uygun olarak uygulamaya geçirilmiştir. Araştırma sürecinin ilk haftasını öğretmen adayları okulu ve rehber öğretmeni tanıma süreciyle, sonraki beş haftasını gözlem faaliyetleriyle ve son sekiz haftasını ise uygulama etkinlikleriyle geçmişlerdir (bkz. Tablo 1).

\section{Tablo 1.}

Öğretmenlik Uygulama Süreci

\begin{tabular}{|c|c|}
\hline Hafta & Etkinlikler \\
\hline \multirow[t]{2}{*}{ 1. Hafta } & 1. Dönem planı \\
\hline & 2. Grubu tanıma, dersle ilgili bilgiler ve uygulama okulunun tanıtımı \\
\hline \multirow[t]{2}{*}{ 2. Hafta } & 1.Öğretmenin okuldaki bir günü \\
\hline & 2. Öğretmenin kullandığı öğretim yöntemleri \\
\hline 3. Hafta & 1. Öğretmenin sınıf yönetimi ve sınıfın kontrolü \\
\hline \multirow[t]{2}{*}{ 4. Hafta } & 1.Yapılandırıcı yaklaşımda öğretmen \\
\hline & 2. Derste yararlanılan etkinlikler ve öğrenci çalışmalarını değerlendirme \\
\hline \multirow[t]{2}{*}{ 5. Hafta } & 1. Soru sormayı ve okulda kullanılan araç-gereç ve kaynakları gözlemleme \\
\hline & 2. Ders planı yapma ya da arkadaşının dersi nasıl işlediğini gözlem formuyla gözleme \\
\hline \multirow[t]{2}{*}{ 6. Hafta } & 1. Öğretmenin dersi nasıl işlediğini gözlem formuyla gözleme \\
\hline & 2. Ders planı yapma ya da arkadaşının dersi nasıl işlediğini gözlem formuyla gözleme \\
\hline 7.Hafta & $\begin{array}{l}\text { 1. Ders planı yapma/arkadaşının dersi nasıl işlediğini gözlem formuyla gözleme/vaka kaydı } \\
\text { oluşturma }\end{array}$ \\
\hline 8. Hafta & $\begin{array}{l}\text { 1. Ders planı yapma/arkadaşının dersi nasıl işlediğini gözlem formuyla gözleme/vaka kaydı } \\
\text { oluşturma }\end{array}$ \\
\hline 9. Hafta & $\begin{array}{l}\text { 1. Ders planı yapma/arkadaşının dersi nasıl işlediğini gözlem formuyla gözleme/vaka kaydı } \\
\text { oluşturma }\end{array}$ \\
\hline 10. Hafta & $\begin{array}{l}\text { 1. Ders planı yapma/arkadaşının dersi nasıl işlediğini gözlem formuyla gözleme/vaka kaydı } \\
\text { oluşturma }\end{array}$ \\
\hline 11. Hafta & $\begin{array}{l}\text { 1. Ders planı yapma/arkadaşının dersi nasıl işlediğini gözlem formuyla gözleme/vaka kaydı } \\
\text { oluşturma }\end{array}$ \\
\hline 12. Hafta & $\begin{array}{l}\text { 1. Ders planı yapma/arkadaşının dersi nasıl işlediğini gözlem formuyla gözleme/vaka kaydı } \\
\text { oluşturma }\end{array}$ \\
\hline 13. Hafta & $\begin{array}{l}\text { 1. Ders planı yapma/arkadaşının dersi nasıl işlediğini gözlem formuyla gözleme/vaka kaydı } \\
\text { oluşturma }\end{array}$ \\
\hline 14. Hafta & $\begin{array}{l}\text { 1. Ders planı yapma/arkadaşının dersi nasıl işlediğini gözlem formuyla gözleme/vaka kaydı } \\
\text { oluşturma }\end{array}$ \\
\hline
\end{tabular}

Araştırmada ilk hafta grubu tanıma, dersle ilgili bilgi verme ve uygulama okulunun tanıtımı ile tamamlanmıştır. Illk hafta, aynı zamanda, öğretmen adayları araştırmayı yürüten öğretim üyesi eşliğinde uygulama yapacakları okulları ziyaret etmişler ve okul personeli (okul müdürü, uygulama öğretmenleri, diğer öğretmenler) ile tanışmışlardır. Bu ziyaret esnasında, öğretmen adaylarının uygulama yapacakları ders gün ve saatleri belirlenmiştir. Öğretmen adayları her hafta iki günü uygulama okullarında geçirmişler; uygulama yapmadıkları günleri gözlem faaliyeti yaparak icra etmişlerdir. Öğretmen adayları ilk beş haftayı gözlem yaparak, geriye kalan son sekiz haftayı ise uygulama yaparak geçirmişlerdir. ilk beş haftaya ilişkin olarak, öğretmen adayları yaptıkları gözlemleri öğretim elemanı ile paylaşmışlar; yapılan gözlemler tartışılarak etkili ve verimli bir dersin nasıl olması gerektiğine ilişkin çıkarımlarda bulunulmuştur. Gözlem yapma sürecinin ardından, öğretmen adayları uygulama sürecine geçmişlerdir. 
Her öğretmen adayı iki haftada bir kez en az bir ders saati olmak üzere uygulama yapma olanağı elde etmiştir. Öğretmen adaylarının uygulamaya ilişkin yaptıkları ders planları her hafta öğretim elemanı tarafından gözden geçirilmiş olup, onlara bu doğrultuda gerekli geribildirimler sağlanmıştır. Öğretim elemanı, her hafta öğretmen adaylarıyla en az bir saat zaman geçirerek hem uygulamaları değerlendirmiş hem de ders planlarına yönelik geribildirim verme imkânı elde etmiştir. Bunun yanı sıra, öğretim elemanı öğretmen adayları üzerinde gözlemlerde bulunabilmek için zaman zaman uygulama okullarına ziyaretler gerçekleştirmiştir. Öğretim elemanı, bu gözlemlerden elde ettiği sonuçları eğitim fakültesindeki derslerde öğretmen adayları ile paylaşmış olup, etkili bir derse ilişkin geribildirimler sunmuştur. Ayrıca, öğretim elemanı zaman zaman da öğretmen adaylarının ders videolarını izlemiş ve onlara derslere ilişkin geribildirimler sağlamıştır.

\section{Veri Toplama Araçları}

Araştırmada nicel verilerin toplanmasında "Öğretmenlik Mesleğine Yönelik Tutum Ölçeği” ile "Öğretmenlerin Özyeterlik İnancı Ölçeği" kullanılırken, nitel verilerin toplanmasında ise "gözlem formu", "görüşme formu" ve "günlük formu" işe koşulmuştur. Araştırmada kullanılan ölçek ve formlara ilişkin açıklayıcı bilgiler; "nicel veri toplama araçları" ve "nitel veri toplama araçları" başlıkları altında ele alınarak kısaca betimlenmeye çalışılmıştır.

\section{Nicel Veri Toplama Araçları}

Öğretmenlik Mesleğine Yönelik Tutum Ölçeği. Öğretmenlerin adaylarının öğretmenlik mesleğine yönelik tutumunu inceleyebilmek için Üstüner (2006) tarafından geliştirilen “Öğretmenlik Mesleğine Yönelik Tutum Ölçeği” kullanılmıştır. Ölçek, toplam 34 maddeden meydana gelmekte olup, maddelerin tümü 5'li Likert formattadır ( 1 = kesinlikle katılmıyorum; 2 = katılmıyorum; $3=$ kararsızım; $4=$ katılıyorum; $5=$ kesinlikle katılıyorum). Ölçekteki maddelerin 14 tanesi olumlu yargı içermekteyken, geriye kalan 10 madde ise içerisinde olumsuz yargı içermektedir. Bunun yanı sıra, ölçek tek boyutludur (34 madde; örn., "Bilgili ve yeterli bir öğretmen olacağımı düşünüyorum"; $\alpha=.93)$. Ayrıca, ölçekten elde edilen güvenirlik katsayısı, ölçeğin kullanılabilmesi için mükemmel bir değere sahip olduğunu göstermiştir (Üstüner, 2006).

Öğretmen Özyeterlik Inancı Ölçeği. Öğretmen adaylarının özyeterlik inancını inceleyebilmek için TschanenMoran ve Hoy (2001) tarafından geliştirilen ve Çapa, Çakıroğlu ve Sarıkaya (2005) tarafından Türkçeye uyarlanan "Öğretmen Özyeterlik İnancı Ölçeği” kullanılmıştır. Ölçek, toplam 24 maddeden meydana gelmekte olup, maddelerin tümü 5'li Likert formattadır (1 = kesinlikle katılmıyorum; 2 = katılmıyorum; 3 = kararsızım; 4 = katılıyorum; 5 = kesinlikle katılıyorum). Bunun yanı sıra, ölçek üç boyutludur; (a) öğrenci katılımına yönelik özyeterlik (8 madde; örn., "Çalışması zor öğrencilere ulaşmayı ne kadar başarabilirsiniz?”; $\alpha=.82$ ), (b) öğretim stratejilerine yönelik özyeterlik (8 madde; örn., "Öğrencilerin zor sorularına ne kadar iyi cevap verebilirsiniz?”; $\alpha$ $=.86$ ), (c) sınıf yönetimine yönelik özyeterlik (8 madde; örn., "Sınıfta dersi olumsuz yönde etkileyen davranışları kontrol etmeyi ne kadar sağlayabilirsiniz?”; $\alpha=.84)$. Ayrıca, ölçekten elde edilen güvenirlik katsayılarının, ölçeğin kullanılabilmesi için iyi değerlere sahip olduğunu göstermiştir. Bununla birlikte, ölçeğe uygulanan doğrulayıcı faktör analizi sonuçları da (TLI = .99; CFI = .99; RMSEA = .07) ölçeğin kullanılabilmesi için kabul edilebilir değerlere sahip olduğunu göstermiştir (Çapa, Çakıroğlu \& Sarıkaya, 2005).

\section{Nitel Veri Toplama Araçları}

Görüşme Formu. Araştırmada görüşmenin temel amacı, ilgi duyulan bir konu veya merak edilen bir soru hakkında bilgi toplamaktır (Patton, 2002). Görüşme, gözlemleyemediğimiz davranışlar, duygular veya insanların etrafındaki dünyayı nasıl ifade ettiklerini öğrenmek için gereklidir (Merriam, 1998). Bu bakımdan, araştırmada verilerin çeşitlendirilmesinde, dolayısıyla daha anlamlı verilerin toplanmasına katkı yapabileceği düşünülen görüşme yönteminin çalışma kapsamında kullanılması düşünülmüştür (Creswell, 2013). Dolayısıyla, araştırmada öğretmen adaylarının öğretmenlik mesleğine yönelik tutumu ile özyeterlik inançlarını inceleyebilmek için yarıyapılandırılmış bir görüşme formu kullanılmıştır. Görüşme formunun hazırlanmasında alanyazın taraması yapılarak, öğretmenlik mesleğine yönelik tutum ve özyeterlik inançları ile ilgili form ve ölçekler incelenmiştir. Alanyazına dayalı olarak incelenen bu form ve ölçekler doğrultusunda toplam sekiz adet açık uçlu soru hazırlanmıştır. Hazırlanan bu sorular dilbilim ve eğitim bilimleri alanlarından uzmanların görüşlerine sunulmuş; bu uzmanlardan gelen geribildirimler neticesinde sorular pilot uygulamaya tabi tutulmuştur. Araştırmada, hazırlanan görüşme formu farklı öğretmen adaylarının oluşturduğu beş kişilik bir grup içerisinde uygulanmış, böylelikle soruların anlaşılabilirliği, kullanışlılığı ve amaca hizmet etme durumları incelenmiştir. Hazırlanan görüşme formu gerçekleştirilen pilot uygulama sonrasında gözden geçirilerek, form üzerinde bazı düzeltmeler (örn., sorulara sondaların eklenmesi, bazı sorularının yerlerinin değiştirilmesi, vb.) yapılmıştır. Görüşme formu, üzerinde gerekli değişiklikler yapıldıktan sonra kullanıma hazır hale getirilmiştir. 
Gözlem Formu. Gözlem, nitel araştırmalarda işe koşulan temel yöntemlerden birini teşkil etmektedir (Creswell, 2013). Gözlem, araştırmada intiyaç duyulan verilerin insan, toplum ya da bir araç kullanılarak izlenmesi suretiyle toplanması sürecini tanımlamaktadır (Merriam, 1998). Nitel veri toplamada önemli bir kaynak durumunda olan gözlem, sosyal olaylardaki karmaşıklığın açıklığa kavuşturulmasında temel yardımcılardan biridir (Patton, 2002). Bu amaçla, öğretmen adaylarının öğretmenlik mesleğine yönelik tutumu ile özyeterlik inançlarını inceleyebilmek için yarı-yapılandırılmış bir gözlem formu kullanılmıştır. Gözlem formu, "öğretmenlik mesleğine yönelik tutum" ve "öğretmenlik özyeterlik inancı" boyutlarından meydana gelmiştir. Hazırlanan bu formdaki "öğretmenlik mesleğine yönelik tutum” boyutu öğretmenlik mesleği davranışları, öğretmenlik mesleğine yönelik ilgi ve sevgi ve öğretmenlik mesleğini yapmaya yönelik istek olmak üzere toplam üç alt-boyuttan meydana gelmiştir. Bunun yanı sıra, hazırlanan bu formdaki "öğretmenlik özyeterlik inancı" boyutu ise öğrenci katılımını sağlama, öğretim stratejilerini kullanma ve sınıf yönetimi olmak üzere toplam üç alt-boyuttan oluşmuştur. Hazırlanan bu form eğitim bilimleri alanından uzmanların görüşlerine sunulmuş; bu uzmanlardan gelen geribildirimler neticesinde sorular pilot uygulamaya tabi tutulmuştur. Araştırmada, hazırlanan gözlem formu farklı öğretmen adaylarının oluşturduğu bir grup içerisinde uygulanmış, böylelikle formdaki boyutların amaca hizmet etme durumları incelenmiştir. Gözlem formu, üzerinde gerekli değişiklikler yapıldıktan sonra kullanıma hazır hale getirilmiştir.

Günlük Formu. Günlükler, araştırmaya katılan bireylerin yaşadıkları deneyimleri aktarmaları açısından bir doküman niteliği taşımaktadır (Glesne, 2011). Günlük gibi dokümanların incelenmesi, dokümanı hazırlayan kişinin bireysel bakış açııını vermesi bakımından önem taşımaktadır (Merriam, 1998). Bu amaçla, öğretmen adaylarının öğretmenlik mesleğine yönelik tutumu ile özyeterlik inançlarını inceleyebilmek için bir günlük formu hazırlanmıştır. Hazırlanan günlük formu, "öğretmenlik mesleğine yönelik tutum” ve "öğretmenlik özyeterlik inancı" boyutlarından meydana gelmiştir. Hazırlanan bu formdaki "öğretmenlik mesleğine yönelik tutum" boyutu öğretmenlik mesleği davranışları, öğretmenlik mesleğine yönelik ilgi ve sevgi ve öğretmenlik mesleğini yapmaya yönelik istek olmak üzere toplam üç alt-boyuttan meydana gelmiştir. Bunun yanı sıra, hazırlanan bu formdaki "öğretmenlik özyeterlik inancı" boyutu ise öğrenci katılımını sağlama, öğretim stratejilerini kullanma ve sınıf yönetimi olmak üzere toplam üç alt-boyuttan meydana gelmiştir. Hazırlanan bu form eğitim bilimleri alanından uzmanların görüşlerine sunulmuş; bu uzmanlardan gelen geribildirimler neticesinde sorular pilot uygulamaya tabi tutulmuştur. Pilot uygulama neticesinde, geliştirilen günlük formu üzerinde gerekli düzeltmeler yapılarak kullanılama hazır duruma getirilmiştir.

\section{Veri Toplama Süreci}

Araştırmada verilerin toplanma süreci iki aşamada gerçekleştirilmiş olup, bu aşamaları "nicel verilerin toplanması" ve "nitel verilerin toplanması" oluşturmuştur.

\section{Nicel Verilerin Toplanması}

Araştırmada nicel verilerin toplanması süreci, "Öğretmenlik Mesleğine Yönelik Tutum Ölçeği" ile “Öğretmenlerin Özyeterlik İnancı Ölçeği”nin öğretmen adaylarına öntest olarak uygulanması ile başlamıştır. 14 hafta süreyle öğretmen adayları öğretmenlik uygulamalarını gerçekleştirmişlerdir. Araştırmanın sonunda, aynı veri toplama araçları öğretmen adaylarına sontest olarak uygulanmıştır. Araştırmada veri toplama süreci Şubat ayında başlayarak, Haziran ayında tamamlanmıştır. Araştırmada, veri toplama araçlarının uygulanması yaklaşık olarak 15 dakika sürmüştür.

\section{Nitel Verilerin Toplanması}

Araştırmada, nicel verilerin toplanması sürecinin akabinde nitel veri toplama araçları işe koşulmuştur. Nitel veri toplama araçlarından olan gözlem ve günlük formları öğretmenlik uygulaması süreci içerisinde uygulanmıştır. Araştırmada, öğretmen adayları üzerinde üç haftada bir gözlem faaliyetleri yürütülmüş, böylece üç haftalık gözlem verisi elde edilmiştir. Ayrıca, öğretmen adayları her haftanın sonunda günlük formlarını doldurmuşlar ve bu formları dosyalarına koymuşlardır. Öğretmenlik uygulaması sürecinin sona ermesi ile birlikte, görüşme formu öğretmen adaylarına uygulanmıştır. Öğretmen adayları ile yapılan görüşmeler toplam üç gün sürmüş olup, yapılan bu görüşmeler odak grup görüşmesi şeklinde gerçekleştirilmiştir (Krueger, 1994). Çalışmada, beşer öğretmen adayından meydana gelen toplam üç adet odak görüşme grubu oluşturulmuştur. Odak grup görüşmesinde grup olarak cevap verildiği için bazı katılımcıların vermiş olduğu cevaplar, diğer katılımcıları konu ile alakalı hususları hatırlamalarını ve araştırmaya katkı yapmalarını sağlamaktadır (Creswell, 2012). Odak grup görüşmesiyle araştırmacı, aynı zamanda, görüşmeye katılanların herhangi bir olgu veya olay hakkında ortaklaşa nasıl algıladıklarını görme fırsatı yakalamaktadır (Berg \& Lune, 2011). Bu şekilde araştırmacı, grubun ortak eğilimlerini, yaşantılarını, düşüncelerini ve duygularını yakından görme imkânı elde etmiştir. Diğer yandan, yapılan görüşmeler araştırmacı tarafından görüşme sürecinde yazıya dökülmüştür. Görüşmeler 
sırasında kullanılabilecek ses veya görüntü kayıt cihazlarının görüşmelerin doğallıı̆̆ını bozabileceği endişesi ile araştırmada kayıt cihazı kullanılmamıştır (Glesne, 2011). Araştırmacı, görüşme ortamının doğalıktan uzak olması durumunda, görüşme yoluyla elde edilen verilerin de doğallıktan uzak olabileceğini düşünmüştür. Ancak, odak grup görüşmeleri teyp kaydına alınmadığında, görüşmeden sonra çok kısa bir süre içerisinde yazıya dökülmezse görüşmenin yeniden yapılandırılabilmesi güç olmaktadır (Bogdan \& Biklen, 2003). Bu sebeple, araştırmacı öğretmen adaylarının görüş ve düşüncelerini kısaltarak notlar almış, daha sonra bunları aynı gün içerisinde metne dökmüştür. Daha sonra, metne dökülen görüşmeler öğretmen adaylarına gösterilerek, bu görüş ve düşüncelerin kendilerine ait olup olmadığını teyit etmeleri istenmiştir. Aynı zamanda, öğretmen adaylarının belirttikleri görüş ve düşüncelere eklemeler yapabilmelerinin yanı sıra, istedikleri görüş ve düşüncelerin de metinden çıkarılmasına izin verilmiştir.

\section{Verilerin Analizi}

Araştırmada, verilerin analizi iki aşamada gerçekleştirilmiş olup, bu aşamaları "nicel verilerin analizi" ve "nitel verilerin analizi" oluşturmuştur.

\section{Nicel Verilerin Analizi}

Araştırma grubundan sağlanan veriler uygun istatistik analizlerin yapılabilmesi için SPSS 22.0 paket programına kaydedilmiştir. Araştırmada, toplanan nicel verilerin istatistik analizlerine geçmeden önce verilerin normal dağııım gösterip göstermediği ve varyanslarının dağııımları arasında anlamlı farklıık olup olmadığı kontrol edilmiştir. Bu araştırmada, araştırma grubunun büyüklüğünün $30^{\prime}$ dan az olmasından dolayı, verilerin normal dağılım gösterip göstermediğini kontrol etmede Shapiro-Wilk testinin işe koşulması uygun bulunmuştur (Howell, 2006). Araştırmada, nicel verilerin toplanmasında kullanılan "Öğretmenlik Mesleğine Yönelik Tutum Ölçeği" ( $\left.W_{\text {öntest }}=.95, p=.48, p>.05\right)$ ve "Öğretmen Özyeterlik Inancı Ölçeği" ( $\left.W_{\text {öntest }}=.93, p=.30, p>.05\right)$ öntest sonuçlarından ve "Öğretmenlik Mesleğine Yönelik Tutum Ölçeği" ( $\left.\mathrm{W}_{\text {sontest }}=.90, p=11, p>.05\right)$ ile "Öğretmen Özyeterlik İnancı Ölçeği" ( $\left.\mathrm{W}_{\text {sontest }}=.96, p=.77, p>.05\right)$ son-test sonuçlarından elde edilen verilerin Shapiro-Wilk testi sonuçları, toplanan verilerin normal dağıııma sahip olduğunu göstermiştir (Gall, Gall \& Borg, 2003). Dolayısıyla, çalışmanın nicel verilerinin analizinde parametrik test istatistiklerinin kullanılması uygun görülmüştür (Creswell, 2012). Ayrıca, araştırmanın nicel alt problemlerini yanıtlayabilmek için grup-içi karşılaştırmalar yapılmıştır. Çalışmada, grup-içi karşılaştırmalarda bağımlı gruplar $t$-testi kullanıımışır (Gall, Gall \& Borg, 2003). Aynı zamanda, araştırma grubunun ölçeklerden elde ettiği puanların aritmetik ortalama ve standart sapma gibi değerlerinin verilmesinde betimsel istatistikler kullanılmıştır (Shavelson, 2012).

\section{Nitel Verilerin Analizi}

Çalışmada, öncelikle, nitel verileri analiz etmeye başlamadan önce, öğretmen adaylarından toplanan veriler araştırmacı tarafından bilgisayar ortamına aktarılmıştır. Microsoft Office (MS) Word 2007 paket programına kaydedilen tüm nitel veriler tarihine ve türüne (gözlem, görüşme, günlük) göre ayrı ayrı sınıflandırılmıştır. Araştırmada nitel verilerin analizi sürecine geçilmeden hemen önce ilgili alanyazına (Bogdan \& Biklen, 2003; Denzin \& Lincoln, 2005) dayalı olarak bir kod listesi oluşturulmuştur. Araştırmada, öğretmen adaylarından elde edilen görüşme verilerine ÖA, gözlem verilerine $G Z$ ve günlük verilerine ise $G N$ kodları verilmiştir. Çalışmada elde edilen verilerin analizinde ise, içerik analizi kullanılmıştır (Berg \& Lune, 2011; Miles \& Huberman, 1994). İçerik analizinde birbirine benzeyen veriler, belirli kavramlar ve temalar etrafında bir araya getirilmekte ve okuyucunun anlayabileceği bir şekilde düzenlenerek yorumlanmaktadır (Patton, 2002). Iç̧erik analizi yöntemi ile araştırma sonuçlarına göre önceden belirlenen temalar göre bir analiz değil, daha derinlemesine ve daha fazla sayıda temaya ulaşılması hedeflenmektedir (Miles \& Huberman, 1994). İçerik analizi için toplanan nitel veriler araştırmacı tarafından iki kez kesintisiz ve dört-beş kez de aralıklı zamanlarda okunarak veriler kodlanmıştır. Nitel veri seti, sürekli olarak araştırmacı tarafından okunmuş ve çıktısı alınan veriler üzerinde taslak kodlamalar yapılmıştır. Bu şekilde, birkaç kez taslak kodlamalar yapılmıştır. Böylece, birkaç kez yapılan taslak kodlamalar birbirleriyle karşılaştııılarak, kodlamaların tutarılı̆̆ının sağlanmasına çalışılışıı. Daha sonra, yapılan taslak kodlamaların ardından asıl kodlama sürecine geçilerek, buradan kodların anlamlı örüntüler oluşturabileceği temalara ulaşılmıştır (Auerbach \& Silverstein, 2003). Analiz edilen nitel verilerin ve ulaşılan temaların inandırıcılı̆̆ı ve aktarılabilirliği ile ilgili çalışmalar gerçekleştirildikten sonra, çalışma verilerin betimlenmesi ve raporlaştırılması aşamaları ile son bulmuştur.

\section{Nitel Verilerin İnandırıcılığı ve Aktarılabilirliğ}

Nitel araştırmalarda toplanan verilerin inandırıcılığı ve aktarılabilirliği sağlamak oldukça önemlidir (Denzin \& Lincoln, 2005). Bunun için araştırma verilerinin toplanmasında inandırıcılığa ve aktarılabilirliğe ilişkin önlemlerini almak büyük bir öneme sahip bulunmaktadır (Bogdan \& Biklen, 2003). Bu nitel araştırmada elde 
edilen verilerin inandırıcılığını sağlayabilmek için çeşitleme, derinlik odaklı veri analizi, uzun süreli etkileşim sağlama ve katılım teyidi gibi teknikler işe koşulmuştur (Erlandson, Harris, Skipper \& Allen, 1993). Çalışmada kullanılan çeşitleme, araştırmacıların kavramsal kategorileri geliştirmelerinde çoklu ve farklı veri kaynaklarını kullanmasını gerektirmektedir (Creswell, 2013). Araştırmacılar, çeşitleme vasıtasıyla olgu ve olaylara ilişkin farklı bakış açılarını çeşitli yollarla ortaya çıkarmaya çalışmışlardır (Patton, 2002). Aynı zamanda, araştırmacılar öğretmenlik uygulamalarının öğretmen adayları üzerindeki katkı ve rolünü anlamak için alanda uzun süreli zaman geçirmişler ve paydaşlarla aralarında güven ilişkisini tesis etmeye çalışmışlardır. Nitekim, alanda uzun süreli zaman geçiren bir araştırmacı olay, olgu, durum ve yorumları katılımcıların bakış açısıyla ortaya koyabilir (Glesne, 2011). Araştırmacılar, bu şekilde, alanda uzun süreli zaman geçirerek daha derinlik odaklı veri toplayabilmişlerdir. Ayrıca, araştırmada elde edilen verilerin ve bunlara ilişkin araştırmacının ulaştığı sonuçların ve yorumların veri kaynakları (katılımcılar) ile teyit edilmesinde de oldukça büyük yarar bulunmaktadır (Yıldırım \& Şimşek, 2008). Bu maksatla, araştırmacılar topladıkları verileri düzenledikten sonra katılımcıların görüşlerine sunarak, öğretmen adaylarının bunların doğruluğuna ilişkin düşüncelerini belirtmelerini istemişlerdir. Bu süreçte, bununla birlikte, araştırmacılar katılımcıların belirttikleri görüşleri veri setinden çıkarmalarına veya yenilerini eklemelerine de imkân sağlamışlardır.

Araştırma bulgularının aktarılabilirliğini sağlamada ise ayrıntılı betimlemeler kullanılmıştır (Patton, 2002). Nitel araştırmalarda bulguların aktarılabilirliği, elde edilen verilerin yeterli düzeyde betimlenmesine bağlı bulunmaktadır (Bogdan \& Biklen, 2003). Nitekim, ayrıntılı betimleme ham verilerin ortaya çıkan kavram ve temalara göre yeniden düzenlenmiş bir şekilde okuyucuya yorum katılmadan ifade edilmesidir (Yıldırım \& Şimşek, 2008). Bu sebeple, araştırmada elde edilen bulgular herhangi bir şekilde yorum katılmadan aktarılmış ve araştırmacılar tarafından sık sık doğrudan alıntılar kullanılmıştır.

\section{Bulgular}

Araştırmanın bu bölümünde; araştırmanın gerek nicel gerekse nitel alt problemlerinin çözümlenebilmesi amacıyla toplanan verilerin analiz edilmesi ile elde edilen bulgulara yer verilmiştir. Bu sebeple, araştırmada elde edilen bulgular "nicel bulgular" ve "nitel bulgular" başlıkları altında verilmiştir.

\section{Nicel Bulgular}

Araştırmada elde edilen nicel bulgular, "öğretmenlik mesleğine yönelik tutum” ve "öğretmen özyeterlik inancın" başlıkları altında incelenmiştir.

\section{Öğretmenlik Mesleğine Yönelik Tutum}

Araştırmada, öğretmen adaylarının öğretmenlik mesleğine yönelik tutum ölçeğinden elde ettikleri ön-test ve son-test puanlarının karşılaştırılabilmesi için bağımlı gruplar t-testi işe koşulmuştur (bkz. Tablo 2).

Tablo 2.

Öğretmenlik Mesleğine Yönelik Tutum Öntest ve Sontest Puanlarının Karşılaştırılması

\begin{tabular}{llccccc}
\hline $\mathrm{n}$ & Test & $\overline{\mathrm{X}}$ & $\mathrm{SS}$ & $\mathrm{sd}$ & $\mathrm{t}$ & $\mathrm{p}$ \\
\hline & Ön-test & 116.64 & 11.75 & & & \\
14 & Son-test & 128.35 & 7.11 & 13 & -3.22 & $.01^{*}$ \\
\hline
\end{tabular}

Not. ${ }^{*} p<.05$

Tablo 2'ye bakıldığında, öğretmen adaylarının öğretmenlik mesleğine yönelik tutum ön-test ve son-test puanları arasında istatistiksel olarak anlamlı bir farklılığın $(t(13)=-3.22, p<.05)$ olduğu sonucuna varılmıştır. Elde edilen bu bulgu, öğretmen adaylarının öğretmenlik mesleğine yönelik tutumunun gelişmesinde öğretmenlik uygulamalarının etkili olduğunu göstermiştir.

\section{Öğretmen Özyeterlik Inancı}

Araştırmada, öğretmen adaylarının özyeterlik inancı ölçeğinden elde ettikleri ön-test ve son-test puanlarının karşılaştırılabilmesi için bağımlı gruplar $t$-testi işe koşulmuştur (bkz. Tablo 3). 
Tablo 3.

Öğretmen Özyeterlik Inancı Öntest ve Sontest Puanlarının Karşılaştırılması

\begin{tabular}{|c|c|c|c|c|c|c|c|}
\hline Alt-Ölçek & $\mathrm{n}$ & Test & $\bar{X}$ & SS & $\mathrm{sd}$ & $\mathrm{t}$ & $\mathrm{p}$ \\
\hline \multirow[t]{2}{*}{ Öğrenci Katılımı } & 14 & Ön-test & 54.92 & 8.52 & 13 & -.87 & $.39 *$ \\
\hline & & Son-test & 56.42 & 8.45 & & & \\
\hline \multirow[t]{2}{*}{ Öğretim Stratejileri } & 14 & Ön-test & 53.50 & 10.42 & 13 & -1.81 & $.09 *$ \\
\hline & & Son-test & 57.78 & 9.30 & & & \\
\hline \multirow[t]{2}{*}{ Sınıf Yönetimi } & 14 & Ön-test & 56.85 & 10.00 & 13 & -.10 & $.92 *$ \\
\hline & & Son-test & 57.14 & 8.89 & & & \\
\hline
\end{tabular}

Not. ${ }^{*} p>.05$

Tablo 3'e bakıldığında, öğretmen adaylarının özyeterlik inancı öğrenci katılımına $(t(13)=-.87, p>.05)$, öğretim stratejilerine $(t(13)=-1.81, p>.05)$ ve sınıf yönetimine $(t(13)=-.11, p>.05)$ yönelik özyeterlik ön-test ve son-test puanları arasında istatistiksel olarak anlamlı bir farklılığın olmadığı sonucuna ulaşılmıştır. Elde edilen bu bulgu, öğretmen adaylarının özyeterlik inancının gelişmesinde öğretmenlik uygulamalarının etkili olmadığını ortaya koymuştur. Her ne kadar öğretmenlik uygulamaları sonucunda öğretmen adaylarının özyeterlik inancında anlamlı bir değişme olmasa da, aritmetik ortalamalar karşılaştırıldığında bu konuda gelişmenin yaşandığı görülmüştür.

\section{Nitel Bulgular}

Araştırmada elde edilen nitel bulgular, "öğretmenlik mesleğine yönelik tutum” ve "öğretmen özyeterlik inancı" ana temaları altında kavramsallaştırılmıştır.

\section{Öğretmenlik Mesleğine Yönelik Tutum}

Araştırmada, öğretmenlik mesleğine yönelik tutuma ilişkin olarak elde edilen bulgular üç alt tema altında kavramsallaştırılmıştır (bkz. Tablo 4).

Tablo 4.

Öğretmenlik Mesleğine Yönelik Tutum

\begin{tabular}{ccc}
\hline Ana Tema & Alt Temalar & Nitel Veri Kodu \\
\hline \multirow{3}{*}{ Öğretmenlik } & Öğretmenlik Mesleğine & ÖA-1, ÖA-3, ÖA-4, ÖA-5, ÖA-6, ÖA-7, ÖA-8, ÖA-10, ÖA-11, ÖA- \\
Mesleğine & Yönelik İlgi & 13, ÖA-14, GN-1, GN-2, GN-3, GN-5, GN-6, GN-7, GN-9, GN-10, \\
Yönelik & Öğretmenlik Mesleğine & GN-11, GN-12, GN-13, GZ-2, GZ-3 \\
Tutum & ÖA-1, ÖA-2, ÖA-3, ÖA-4, ÖA-6, ÖA-7, ÖA-8, ÖA-9, ÖA-10, ÖA- \\
& & 12, ÖA-13, ÖA-14, GN-1, GN-2, GN-3, GN-4, GN-5, GN-6, GN-8, \\
& & GN-9, GN-10, GN-11, GN-12, GN13, GZ-2 \\
& Öğretmenlik Mesleğini & ÖA-1, ÖA-3, ÖA-4, ÖA-5, ÖA-6, ÖA-8, ÖA-10, ÖA-13, GN-2, GN- \\
& Yapma İsteği & 4, GN-5, GN-6, GN-7, GN-9, GN-10, GN12, GN-14, GZ-3 \\
\hline
\end{tabular}

Tablo 4'e bakıldığında, öğretmen adaylarının öğretmenlik mesleğine yönelik tutumunun üç alt temada incelendiği görülmektedir. Bu alt temaların "öğretmenlik mesleğine yönelik ilgi”, "öğretmenlik mesleğine yönelik sevgi" ve "öğretmenlik mesleğini yapma isteği" olduğu belirlenmiştir. Araştırmada, ilk olarak ortaya çıkan alt temayı "mesleğe yönelik ilgi" teşkil etmiştir. Öğretmen adaylarının, öğretmenlik uygulamalarının sonunda mesleğe yönelik ilgilerinin arttığı sonucuna ulaşılmıştır.

Okula staj [öğretmenlik uygulamaları] için gitmeden önce, öğretmenlik mesleğine yönelik ilgim çok fazla yoktu diyebilirim. Yani, bu meslek için bir adım atmıştım, ancak açıkçası çok fazla ilgimi çeken bir meslek olduğunu düşünmüyordum. Öğretmenlik uygulamaları ile bu mesleğe olan ilgim gerçekten arttı (ÖA-8).

Bu mesleğe, elbette daha önce bir ilgim vardı, ancak öğretmenlik uygulamaları ile ilgim daha da arttı. Bu uygulamalarda mesleğin bana uygun olduğuna inandım (ÖA-3).

[...] Öğretmenlik uygulanmaları yoluyla öğretmenlik mesleğine yönelik ilgim daha fazla gelişti (GN-11). Öğretmen adayları, öğretmenlik mesleği hakkında daha fazla konuşmaya başladılar. Konuşmalarında öğretmenliğe ilgi duyduklarına ilişkin cümlelerin geçtiği görüldü (GZ-3).

Öğretmenlik mesleğinin bana çok uygun olduğunu düşünüyorum. Bu meslek daha fazla ilgimi çekmeye başladı. Bu mesleği yapacağımı düşünmek beni çok heyecanlandırıyor (ÖA-13). 
Yukarıda verilen alıntılara bakıldığında, öğretmen adaylarının öğretmenlik mesleğine yönelik ilgilerinin giderek arttığı anlaşılmıştır. Araştırmada, bazı öğretmen adaylarının mesleğe yönelik ilgilerinin öğretmenlik uygulamalarından önce düşük iken, bu uygulamalarla birlikte ilgilerinin arttığı görülmüştür. Ayrıca, araştırmada öğretmen adaylarının öğretmenlik uygulamaları yoluyla mesleğe yönelik ilgilerinin yanı sıra sevgilerinin de gelişme gösterdiği sonucuna ulaşılmıştır.

Öğretmenlik mesleğini çok seviyorum. Öğretmenlik uygulamaları vasıtasıyla bu mesleğe yönelik sevgim daha fazla arttı (ÖA-7).

Öğretmenlik mesleği bana çok çekici gelmeye başladı. Tabiî ki, öğretmenlik uygulamalarının bundaki rolünü kesinlikle yadsıyamam. Bu uygulamalar sayesinde öğretmenlik mesleğini daha fazla sevmeye başladım (GN-6).

Öğretmenlik mesleğine yönelik daha önce gerçekten çok fazla sevgim yoktu. Ancak, öğretmenlik uygulamaları yoluyla bu mesleğe ilişkin sahip olduğum sevgi daha fazla gelişti (ÖA-9).

[...] Öğretmen adaylarının, okullara uygulama için gittiklerinde öğretmenlik mesleğini daha fazla sevdikleri gözlenmiştir. Öğretmen adayları, okullara uygulama için gittikleri günlerde çok mutlu olduklarını dile getirdikleri görülmüştür (GZ-2).

Esasen, öğretmenlik uygulamalarından önce bu mesleğini çok fazla sevdiğimi söyleyemem. Ama, bu uygulamalar sayesinde gerçekten öğretmen mesleğini sevdiğimi anladım (ÖA-1).

Yukarıdaki alıntılara bakıldığında, öğretmen adaylarının öğretmenlik uygulamaları sayesinde öğretmenlik mesleğini sevdikleri anlaşımıştır. Araştırmada, bazı öğretmen adaylarının mesleğe yönelik sevgilerinin öğretmenlik uygulamalarından önce düşük iken, bu uygulamalarla birlikte sevgilerinin arttığı görülmüştür. Ayrıca, araştırmada öğretmen adaylarının öğretmenlik uygulamaları yoluyla mesleği ileride yapmaya yönelik isteğe sahip oldukları sonucuna varılmıştır.

Öğretmenlik uygulamalarından sonra öğretmenlik mesleğini ileride yapmaya yönelik isteğim daha fazla arttı. İlk başta, mezun olduktan sonra belki bu mesleği yapmayabilirim diye düşünüyordum, ama öğretmenlik uygulamalarından sonra kesinlikle bu mesleği yapmaya yönelik isteğim gelişme gösterdi (ÖA-5).

Ileride öğretmenlik mesleğini yapmayı çok istiyorum. [...] Bu mesleğin bana gerçekten çok uygun olduğunu düşünüyorum (GN-12).

Kesinlikle bu mesleği ileride yapmayı çok istiyorum. Bu mesleği bir an önce yapabilmek için gerçekten sabırsızlanıyorum (ÖA-4).

Öğretmenlik mesleğini icra etmeyi çok istiyorum. Bu meslek sahip olduğum özelliklere çok uygun.

Kendi öğrencilerimin olmasını ve öğretmenlik yapmayı çok istiyorum (ÖA-6).

Yukarıdaki alıntılarda da görüldüğü üzere, öğretmen adaylarının ileride öğretmenlik mesleğine yapmaya yönelik isteklerinin gelişme gösterdiği anlaşılmıştır. Araştırmada, öğretmen adaylarının bir an önce öğretmenlik mesleğine başlayarak, ileride bu mesleği icra etmek istedikleri sonucuna ulaşılmıştır.

\section{Öğretmen Özyeterlik Inancı}

Araştırmada, öğretmen özyeterlik inancına ilişkin olarak elde edilen bulgular üç alt tema altında kavramsallaştırılmıştır (bkz. Tablo 5).

Tablo 5

Öğretmen Özyeterlik Inancı

\begin{tabular}{|c|c|c|}
\hline Ana Tema & Alt Temalar & Nitel Veri Kodu \\
\hline & $\begin{array}{l}\text { Öğrenci Katılımına Yönelik } \\
\text { Özyeterlik }\end{array}$ & $\begin{array}{l}\text { ÖA-2, ÖA-3, ÖA-5, ÖA-6, ÖA-8, ÖA-9, ÖA-11, ÖA-12, ÖA-14, GN- } \\
2 \text {, GN-4, GN-5, GN-8, GN-10, GN-11, GN-13, GN-14, GZ-1, GZ-2, }\end{array}$ \\
\hline Öğretmen & & GZ-3 \\
\hline \multirow[t]{2}{*}{$\begin{array}{l}\text { Özyeterlik } \\
\text { İnancı }\end{array}$} & $\begin{array}{l}\text { Öğretim Stratejilerine } \\
\text { Yönelik Özyeterlik }\end{array}$ & $\begin{array}{l}\text { ÖA-1, ÖA-2, ÖA-4, ÖA-6, ÖA-7, ÖA-9, ÖA-10, ÖA-11, ÖA-12, ÖA- } \\
\text { 14, GN-2, GN-4, GN-6, GN-7, GN-8, GN-11, GN-14, GZ-1, GZ-2, } \\
\text { GZ-3 }\end{array}$ \\
\hline & $\begin{array}{c}\text { Sınıf Yönetime Yönelik } \\
\text { Özyeterlik }\end{array}$ & $\begin{array}{l}\text { ÖA-1, ÖA-2, ÖA-3, ÖA-4, ÖA-6, ÖA-8, ÖA-9, ÖA-10, ÖA-11, ÖA- } \\
\text { 13, ÖA-14, GN-1, GN-2, GN-5, GN-7, GN-9, GN-12, GN-14, GZ-1, } \\
\text { GZ-3 }\end{array}$ \\
\hline
\end{tabular}

Tablo 5’e bakıldığında, öğretmen adaylarının özyeterlik inancının üç alt temada incelendiği görülmektedir. Bu alt temaların "öğrenci katılımına yönelik özyeterlik”, “öğretim stratejilerine yönelik özyeterlik" ve "sınıf yönetime yönelik özyeterlik" olduğu belirlenmiştir. Araştırmada, ilk olarak ortaya çıkan alt temayı "öğrenci 
katılımına yönelik özyeterlik" teşkil etmiştir. Öğretmen adaylarının, öğretmenlik uygulamalarının sonunda öğrenci katııımını sağlamaya yönelik yeterlik inancının gelişme göstermediği sonucuna ulaşıımıştır.

Öğrencilerini derse nasıl katacağıma ilişkin yolları bilmiyorum. Yani, öğrencileri derse katmada kendimi yeterli hissetmiyorum. Ne yaparsam yapayım, öğrencileri etkili olarak derse katamıyorum (ÖA-2).

Açıkçası, öğrencileri derse katmada kendimi yeterli görmüyorum. Sınıfta tek yaptığım öğrencilere soru sormak. Yalnızca soru sorarak öğrencileri derse katamıyorum (ÖA-12).

[...] özellikle, dersi sadece kendimin anlattığının farkındayım. Öğrencileri derse katmada tek kullandı̆̆ım yol soru sormak. Bunu geliştirmem gerektiğini düşünüyorum (GN-4).

Öğrencilerin derse etkili olarak katılmasını çok istiyorum. Ama, gerçekten bunu tam olarak nasıl yapmam gerektiğini de bilmiyorum (ÖA-14).

Araştırmada, öğretmen adaylarının öğrenci katıımını sağlamada yetersiz olduklarını ifade ettikleri görülmüştür. Öğretmen adayları, öğrenci katııımını sağlamada yetersiz olduklarını dile getirirlerken, sınıfta öğrenci katııımını sağlamada kullandıkları tek yolun ise soru-cevap tekniği olduğunu belirtmişlerdir. Araştırmada ortaya çıkan bu bulgu, ayrıca, bazı gözlem sonuçlarına da yansımıştır.

Öğretmen adayının öğrencileri derse katmada soru-cevap tekniğini kullandığı görülmüştür. Bu tekniği

kullanan öğretmen adayının öğrenci katııımını sağlamada yetersiz olduğu gözlenmiştir (GZ-1).

Öğretmen adayının, öğrencileri derse katmada soru-cevap tekniğini uyguladığı görülmüştür. Ancak, bu teknikle öğrenci katılımının çok sınırı bir düzeyde kaldığı gözlenmiştir (GZ-2).

Gözlem kaydına ilişkin alıntılara bakıldı̆̆ında, öğretmen adaylarının öğrenci katımını sağlamada yetersiz oldukları anlaşılmıştır. Öğretmen adaylarının öğrenci katılımını sağlamada yalnızca soru-cevap tekniğini işe koştukları tespit edilmiştir. Ayrıca, araştırmaya katılan öğretmen adayları öğrenci motivasyonunu sağlayarak, öğrencilere derse katmada yetersizlik yaşadıklarını dile getirmişlerdir.

Esasen, öğrencilerin derse yönelik motivasyon problemleri olduğunu düşünüyorum. Bu yüzden, derse katılmakta oldukça isteksizler. [...] Öğrencilerin motivasyonunu nasıl sağlayarak, onları derse etkin olarak katabileceğim hakkında hiç bir fikrim yok (ÖA-11).

[...] Öğrencilerin derse katılmak için yeterli güdülenmişliğe sahip olmadıklarını düşünüyorum. Onları derse katılmaları için nasıl güdüleyebileceğimi gerçekten bilmiyorum (GN-13).

Sınıfta yalnızca konunun sınavlarda çıkacağından bahsederek, öğrencileri motive etmeye çalışıyorum.

Ama, bunun çok da fazla işe yaradıı̆ını düşünmüyorum (ÖA-3).

Öğretmen adaylarının ifade ettikleri görüşlere bakıldığında, öğrenci motivasyonunu sağlamada yetersizlik hissettikleri anlaşılmıştır. Bununla birlikte, öğretmen adaylarının başarısız öğrencilerin dersi daha iyi anlamasını sağlama hususunda da yetersizlik yaşadıkları sonucuna varılmıştır.

Dersi başarılı öğrencilerle işlemek, bir diğer ifadeyle başarılı öğrencileri derse katmak çok kolay. Esas problemi, başarısız öğrencileri derse katmada yaşıyorum. [...] Sınıfın büyük çoğunluğunun da başarısız öğrencilerden meydana geldiğini düşünürsek, bu öğrencileri derse katmada gerçekten sorun yaşadı̆̆ımı söyleyebilirim (ÖA-6).

Ders çok monoton geçiyor. Genel anlamda, dersin az sayıda öğrenciyle yürütüldüğünü söyleyebilirim. Öğrencilerin çoğunun derse katılımı çok zayıf (GN-5).

Başarısız öğrencileri derse katmakta kendimi gerçekten yetersiz hissediyorum. Çünkü, bir dersin etkili olabilmesi için bütün öğrencilerin derse etkin olarak katılması gerekiyor. Ben, bunu başaramıyorum (ÖA-9).

Öğretmen adayı, sınıftaki birkaç öğrenci ile dersi işlemektedir. Ön sıralarda oturan dört öğrenci ile soru-cevap yollu olarak öğretme-öğrenme sürecini yönlendirmektedir (GZ-3).

Yukarıda verilen alıntılar incelendiğinde, öğretmen adaylarının başarıı öğrencileri derse katmada problem yaşamazken, özellikle sınıfın genelini oluşturan başarısız öğrencileri derse katmada problem yaşadıkları tespit edilmiştir. Bu anlamda, öğretmenlik uygulamalarının öğretmen adaylarının öğrenci katılımını sağlamaya yönelik özyeterlik inancını geliştirmediği ileri sürülebilir. Diğer yandan, araştırmada öğretmen adaylarının öğretim stratejilerini kullanma konusunda yetersizlik duygusuna sahip oldukları sonucuna varılmıştır.

Sınıfta genellikle düz anlatım yöntemini uyguluyorum. Bunun dışında farklı bir öğretim yöntemini uygulamıyorum (ÖA-7).

Öğretmen adayı, çoğunlukla düz anlatım yöntemini uygulamakta. Sadece konuyu anlatma ve soru yoluyla öğrencilerin konuyu anlayıp anlamadıklarını yoklamakta (GZ-1).

Açıkçası, öğretim stratejilerini uygulama konusunda kendimi yeterli hissetmiyorum. Bildiğim birkaç tane strateji var, bunların dışında farklı bir uygulama içerisine girmiyorum (ÖA-9). 
Yukarıdaki alıntılar incelendiğinde, öğretmen adaylarının sınıf içinde farkı öğretim stratejilerini uygulama konusunda yeterli olmadıkları görülmüştür. Ayrıca, öğretmen adayları öğrenciler için uygun öğrenme ortamlarını oluşturmada da kendilerini yetersiz hissettiklerini dile getirmişlerdir.

Sınıf ortamının öğrencilerin etkili öğrenmeleri için uygun olduğunu düşünmüyorum. Ancak, sınıfı nasıl uygun bir öğrenme çevresi haline getirebileceğim hakkında da yeterli fikrim yok (ÖA-10).

Öğretmen adayı ders öncesi sınıf ortamında herhangi bir değişikliğe gitmeden, öğretim faaliyetlerini yürüttü (GZ-2).

Ders öncesi sınıf ortamında herhangi bir değişiklik yapmıyorum. Mevcut öğrenme ortamının öğrenciler için yeterli olmadığını, ancak başka bir şey yapamayacağımı düşünüyorum (GN-8).

Öğretmen adayları, sınıf içinde uygun öğrenme ortamı oluşturma konusunda yetersizlik yaşadıklarıı ifade ederlerken, öğrencilerden gelen bazı sorulara uygun cevaplar bulmakta zorlandıklarını belirtmişlerdir.

Bazen öğrenciler, satıları az da olsa, zorlayıcı sorular sorabiliyorlar. Açıkçası, bu sorular karşısında şaşırıyorum. Cevap veremiyorum (ÖA-12).

Bugün öğrenci bana anlattığım bir konu ile ilgili beni gerçekten zorlayıcı bir soru sordu. Öğrenciye cevap vermekte zorlandım. Bu sorunun cevabını önümüzdeki hafta vereceğimi söyledim (GN-2).

Bazı öğrenci sorularını cevaplamakta zorlanıyorum. [Bu tür sorular] gerçekten zorlayıcı oluyor (ÖA-1).

Öğretmen adayı, parmak kaldırdığını gördü. Bu öğrencinin soru sormasına izin verdi. Öğrenci sorusunu sorduğunda, öğretmen adayı bu sorunun cevabını bilmediğini söyledi (GZ-3).

Verilen alıntılar incelendiğinde, öğretmen adaylarının öğrencilerin sordukları bazı soruları zorlayıcı bulduklarını ve bu sorulara uygun cevaplar bulmakta problem yaşadıklarını ifade ettikleri anlaşılmıştır. Bununla birlikte, öğretmen adayları öğrencilerin kafaları karıştı̆ıında ya da bir konuyu anlayamadıklarında alternatif açıklama ve örnek oluşturmada da kendilerini yetersiz hissettiklerini dile getirmişlerdir.

Bazen bir konuyu anlatırken öğrencilerin o konuyu anlayamadıklarını gözlüyorum. Ancak, öğrencilere o konuyu farklı bir biçimde açıklamakta zorlanıyorum. Farklı açıklama bulmakta zorlanıyorum (ÖA-14). Öğrenciler konuyu anlayamadıklarında benden farklı örnekler istiyorlar. Farklı örnekler versem de, bu örnekler onları çok da tatmin etmiyor. Bu konuda daha farklı bir şeyler yapmam lazım (GN-7).

Yukarıdaki alıntılar incelendiğinde, öğretmen adaylarının öğrencilerin anlamadıkları konuyu daha anlaşıı bir hale getirmek için alternatif açıklama ve örnek üretmede yetersiz oldukları tespit edilmiştir. Öğretmen adaylarının, öğrencilerin bir konuyu anlayamadıklarında, o konuya ilişkin farklı ve daha anlaşılabilir bir açıklama bulmakta zorlandıkları sonucuna ulaşılmıştır. Araştırmada, son olarak ortaya çıkan alt temayı ise "sınıf yönetimine yönelik özyeterlik" teşkil etmiştir. Öğretmen adaylarının, öğretmenlik uygulamalarının sonunda sınıf yönetimine yönelik yeterlik inancının gelişme göstermediği anlaşıımışır.

Sınıfta yürütülen etkinliklerin düzenli bir biçimde yürütülmesinde kendimi yeterli hissetmiyorum. Yani, kendimi sınıf yönetimi alanında çok da yeterli hissettiğimi söyleyemem (ÖA-8).

Sınıfta istenmedik davranış gösteren öğrencilere karşı bir şey yapamıyorum (GN-12).

Ben, şahsen, sınıfta yaramazlık yapan bir öğrenciyi derse yönlendiremiyorum. Bunu nasıl yapacağım konusunda bir bilgim yok (ÖA-13).

[...] Öğretmen adayı, sınıfta ses yapan bir öğrenciyi uyardı. Öğrenci, 2-3 dakika sessiz durduktan sonra, tekrar sesli bir şekilde konuşmaya başladı. Öğretmen adayı, öğrenciyi yine uyardı. Ancak, bu kez öğrenci bu uyarıya aldırış etmeden arkadaşıyla konuşmasını sürdürdü (GZ-1).

Sınıfta, mesela, bir öğrenci var. Hiç kimse umurunda değil. Ders anlatırken beni çok defa sabote etti.

Ama, bu öğrenciye hiçbir şey yapamadım (GN-1).

Verilen alıntılar incelendiğinde, öğretmen adaylarının sınıfta istenmedik öğrenci davranışlarını engellemede kendilerini yetersiz hissettikleri görülmüştür. Bir diğer ifadeyle, öğretmen adayları sınıf yönetiminde yetersizlik duygusu yaşadıklarını ileri sürmüşlerdir. Ayrıca, öğretmen adaylarının sınıfta istenmeyen davranışları kontrol etmede kullandıkları stratejiler de onların sınıf yönetiminde yetersizlik yaşadıklarını göstermektedir.

Yani, olumsuz davranı̧̧ gösteren bir öğrenciyi nasıl kontrol altına alabileceğimi bilmiyorum. Yapabileceğim tek şey, belki, onu sözle uyarmak (ÖA-6).

Ben sınıfta istenmedik davranış gösteren öğrenciyi kontrol etmede [sözlü] uyarıyı kullanıyorum. Bilirsiniz işte, onu okul müdürüne şikâyet edeceğimi söylüyorum (ÖA-14).

Sınıf içinde olumsuz bir davranış gösteren bir öğrenci gördüğümde, ona yalnızca kızmakla yetiniyorum (GN-5).

Sınıfta, örneğin, bir öğrenci var. Elindeki telefonla akıllı tahtayı kontrol ediyor. Bunu, onun yaptığını biliyorum. Bu konuda bir şey de yapamıyorum. Yanına gidip kızdım, ama bana kafasını çevirdi, dinlemedi. Bir keresinde de görmezden geldim, ama yine aynı davranışı yapmayı sürdürdü (ÖA-9). 
Öğretmen adayı, tahtaya yazı yazarken arkasına dönerek çok konuşan bir öğrenciyi sözlü olarak uyardı.

Öğrenci, öğretmen adayını tersleyici yönde bir cevap verdi. Bunun üzerine öğretmen adayı hiçbir şey olmamış gibi davranarak, tahtaya yazı yazmaya devam etti. Sınıfta gülüşmeler meydana geldi (GZ-3).

Yukarıdaki alıntılar incelendiğinde, öğretmen adaylarının sınıfta olumsuz davranış gösteren öğrencileri kontrol altına almakta güçlük yaşadıkları görülmüştür. Araştırmada, öğretmen adaylarının sınıfta olumsuz davranış sergileyen öğrencileri kontrol altına almakta kullandıkları stratejilerin genellikle görmezden gelme ve sözlü olarak uyarma şeklinde olduğu anlaşılmıştır. Ayrıca öğretmen adayları, öğrencilerin sınıf kurullarına uymalarını sağlamada da kendilerini yetersiz hissettiklerini dile getirmişlerdir.

Öğrencilere zaman zaman sınıf kurallarını hatırlatıyorum. Ama, uymadıklarını görüyorum. Bir konuda

bir şey yapamıyorum (ÖA-4).

[...] Öğrencilerin sınıf kurallarına uymalarını sağlayamıyorum (GN-7).

Öğrencilerin, ne yazık ki, sınıf kurallarına uyma bilinçleri yok. Bunu sağlamada gerçekten kendimi yeterli hissetmiyorum (ÖA-10).

Görüldüğü üzere, öğretmen adayları öğrencilerin sınıf kurallarına uymadıklarını dile getirirlerken, onların bu kurallara nasıl uymalarını sağlayacaklarını da bilmediklerini ima etmişlerdir. Öğretmen adayları, öğrencilerin sınıf kurallarına uymaları konusunda problem yaşadıklarını dile getirerek, bu konuda yetersizlik hissi yaşadıklarını ileri sürmüşlerdir.

\section{Tartışma, Sonuç ve Öneriler}

Bu araştırmada, öğretmenlik uygulamalarının öğretmen adaylarının mesleğe yönelik tutum ve özyeterlik inancı üzerindeki etkisi ve rolüne değinilmiştir. Çalışmada, açımlayıcı sıralı karma yöntem deseni kullanılmış ve süreç öncelikle nicel verilerin toplanması, ardından da nicel bulguların nitel verilerle desteklenmesini içermiştir.

Araştırmada elde edilen ilk bulguya göre, öğretmenlik uygulamalarının öğretmen adaylarının mesleğe yönelik tutumu üzerinde istatistiksel olarak anlamlı bir etkisinin olduğu sonucuna ulaşılmıştır. Elde edilen bu bulgu, öğretmenlik uygulamalarının öğretmen adaylarının mesleğe yönelik tutumunu geliştirmede etkili olduğunu göstermiştir. Ayrıca, elde edilen nitel verilerde de, öğretmenlik uygulamalarının öğretmen adaylarının mesleğe yönelik olumlu tutum geliştirmede önemli bir katkısının olduğu anlaşımıştır. Yapılan araştırmada, öğretmen adayları öğretmenlik uygulamaları ile mesleğe yönelik ilgi ve sevgilerinin artarak, ileride bu mesleği yapmaya yönelik isteklerinin de gelişme gösterdiğini ifade etmişlerdir. Konuya ilişkin yapılan araştırmalarda da, pedagojik formasyon eğitimi almakta olan öğretmen adaylarının mesleğe yönelik tutumunun olumlu düzeyde olduğu görülmekle birlikte (Eraslan \& Çakıcı, 2011; Yenice \& Alpak-Tunç, 2016), öğretmenlik mesleğini sevdikleri (Dikmen \& Tuncer, 2018), ilgi duydukları (Özkan, 2012), mesleğe yönelik bağlılık gösterdikleri (Gülşen \& Seyratlı, 2014; Özkan, 2012) ve ileride mesleği icra etmek istedikleri (Gülşen \& Seyratlı, 2014) anlaşılmıştır. Öğretmen adaylarının öğretmenlik mesleğine yönelik olumlu tutum geliştirmeleri, onların bu mesleği icra ederken daha etkili olmalarını sağlayacaktır (Tarman, 2012). Öğretmen adaylarının meslekte başarılı olmaları, onların bu mesleği sevmelerine ve isteyerek icra etmelerine bağlıdır (Aydın \& Sağlam, 2012). Nitekim, öğretmen adaylarının öğretmenlik mesleğine olumlu tutuma sahip olmadan, bu mesleği etkili ve verimli bir biçimde yerine getirebilmeleri pek mümkün gözükmemektedir (Çeliköz \& Çetin, 2004). Bu açıdan, öğretmenlik uygulamalarının öğretmen adaylarının mesleğe yönelik tutum kazanmalarında oldukça önemli bir yere sahip olduğu söylenebilir. Öğretmen adaylarının eğitiminde çok önemli bir yere sahip olan öğretmenlik uygulamaları (Ben-Peretz, 2001), öğretmen adaylarına sınıf içerisinde öğretmenlik becerisi kazandırması (Hacıömeroğlu \& Şahin, 2011; Akpınar, Çolak \& Yiğit, 2012) ve öğretmenlik beceri ve yeterliklerini geliştirmesinin yanı sıra (Sarıçoban, 2008; Tarman, 2012), mesleğe yönelik tutumuna da olumlu katkı sağlamaktadır (Karasu-Avcı \& Ünal-ïbret, 2016). Bu uygulamalar, öğretmen adaylarının kazandıkları bilgileri daha kalıcı izli kılarken, mesleğe yönelik tutumunda da önemli değişiklikler yaratmaktadır (Demirtaş, Cömert \& Özer, 2011). Çünkü, öğretmen adayları mesleğe yönelik olarak olumlu tutum geliştirirlerse, ileride öğretmenlik mesleğini daha etkili ve verimli bir biçimde icra edebilirler (Çeliköz \& Çetin, 2004). Ancak, öğretmenlik uygulamalarının öğretmen adaylarının mesleğe yönelik tutumu üzerindeki etkisini konu alan araştırmaların farklı sonuçlar sunduğu görülmektedir. Bu konuda yapılmış bazı araştırmalar öğretmenlik uygulamalarının öğretmen adaylarının mesleğe yönelik tutumunu olumlu yönde geliştirdiğini gösterirken (Kılıç, 2004; Şişman \& Acat, 2003), bazı araştırmalar ise bu uygulamaların öğretmen adaylarının mesleğe yönelik tutumunu olumsuz yönde etkilediğini ortaya koymaktadır (Koç \& Demirel, 1999; Toprakçı, 2003). Halbuki, bu uygulamalar ile öğretmen adaylarının mesleğe yönelik tutumunda olumlu katkılar sağlanması amaçlanmaktadır (Karasu-Avcı \& Ünal-ibret, 2016). Bu bakımdan, araştırma alanyazınının sunduğu bu sonuçlarda, öğretmen adaylarının okullarda geçirdikleri farklı yaşantıların etkili olabileceği düşünülmektedir. 
Nitekim, öğretmen adaylarının okullarda öğrenciler ve öğretmenlerle etkileşime girmeleri duygu ve düşüncelerini olumlu ya da olumsuz bir biçimde etkileyerek, onların öğretmenlik mesleğine yakınlaşmalarına veya uzaklaşmalarına sebep olabilir (Oğuz, 2004). Bununla birlikte, bu uygulamalarda birtakım sorunlarla karşılaşılıp karşılaşılmamasının da öğretmen adaylarının mesleğe yönelik tutumunu olumlu ya da olumsuz yönde etkileyebileceği düşünülmektedir (Azar, 2003; İnan \& Özgen, 2008). Önemli bir işlevi yerine getiren öğretmenlik uygulamalarının (Aslan \& Sağlam, 2018), öğretmen adaylarının olumsuz deneyimler geçirmemeleri ve mesleğe yönelik olumlu tutum kazanmaları yönünde düzenlenmesi gerekmektedir (Oğuz, 2004). Bu anlamda, öğretmen adaylarının mesleğe yönelik olumlu düşüncelerinin oluşmasında önemli bir role sahip olan bu uygulamaların (Gökçe \& Demirhan, 2005), mesleğinde lider öğretmenlerinin rehberliği altında ve uygun koşullara sahip olan okullarda gerçekleştirilmesi oldukça önemli görülmektedir.

Araştırmada elde edilen bir diğer bulguya göre, öğretmenlik uygulamalarının öğretmen adaylarının özyeterlik inancı üzerinde istatistiksel olarak anlamlı bir etkisinin olmadığı sonucuna varılmıştır. Elde edilen bu bulgu, öğretmenlik uygulamalarının öğretmen adaylarının özyeterlik inancını (öğrenci katılımı, öğretim stratejileri ve sınıf yönetimi) geliştirmede etkili olmadığını göstermiştir. Ayrıca, elde edilen nitel verilerde de, öğretmenlik uygulamalarının öğretmen adaylarının özyeterlik inancını geliştirmede bir katkısının olmadığı anlaşıımıştır. Yapılan araştırmada, öğretmen adayları öğretmenlik uygulamaları ile öğrenci katılımına, öğretim stratejilerine ve sınıf yönetimine yönelik özyeterlik inançlarında bir farklılaşmanın olmadığını ifade etmişlerdir. Konuya ilişkin olarak yapılan araştırmalarda, pedagojik formasyon eğitimi almakta olan öğretmen adaylarının özyeterlik inancının yüksek olduğu rapor edilmektedir (Bakaç \& Özen, 2017; Dadandı, Kalyon \& Yazıcı, 2016; Elkatmış, Demirbaş \& Ertuğrul, 2013). Ancak, konuya ilişkin olarak gerçekleştirilen nitel araştırmalarda ise farklı sonuçlarla karşılaşılmaktadır. Yapılan çalışmalar, öğretmen adaylarının özyeterlik inancı (öğrenci katılımı, öğretim stratejileri ve sınıf yönetimi) konusunda tutarsız sonuçlar sunmaktadır (Ercan-Özaydın, Çavaş \& Cansever, 2017; Şahin-Taşkın \& Hacıömeroğlu, 2010). Ercan-Özaydın, Çavaş ve Cansever (2017) tarafından gerçekleştirilen araştırmada öğretmen adaylarının öğrenci katılımı, öğretim stratejileri ve sınıf yönetimine ilişkin özyeterlik inancı konusunda kendilerini yeterli hissettikleri görülmüştür. Benzer bir biçimde, yapılan başka araştırmalarda da pedagojik formasyon eğitimi almakta olan öğretmen adaylarının öğretme-öğrenme süreci (Akyıldız, 2017; Yalçın \& Akay, 2015) ve ölçme-değerlendirmeye (Erdoğdu \& Kurt, 2012; Yalçın \& Akay, 2015) yönelik olarak kendilerini yeterli hissettikleri tespit edilmiştir. Aksine, Taşkın ve Hacıömeroğlu (2010) tarafından yapılan araştırmada ise öğretmen adaylarının öğrenci katılımı, öğretim stratejileri ve sınıf yönetimine ilişkin özyeterlik inancı konusunda kendilerini yeterli hissetmedikleri tespit edilmiştir. Halbuki, öğretmen adaylarının öğrencileri derse katmada, sınıf içinde uygun öğretim stratejilerini kullanmada ve sınıf yönetimi konusunda yeterliğe sahip olmaları etkili bir öğretme-öğrenme sürecinin oluşturulması için önemli bir husustur (TschanenMoran, Woolfolk-Hoy \& Hoy, 1998). Bir diğer ifadeyle, bu konuda gerekli yeterliğe sahip olmayan öğretmen adaylarının etkili bir öğretme ve öğrenme sürecini yapılandırmaları mümkün gözükmemektedir (TschanenMoran \& Hoy, 2001). Bu araştırmadan elde edilen veriler de, öğretmenlik uygulamalarının öğretmen adaylarının öğrenci katılımına, öğretim stratejilerine ve sınıf yönetimine yönelik özyeterlik inançlarını geliştirmede yetersiz olduğunu ortaya koymuştur. Bu açıdan, öğretmenlik uygulamalarının öğretmen adaylarının özyeterlik inancını geliştirmede yeterli katkıyı yapamadığı söylenebilir. Hâlbuki, öğretmen adaylarının okullarda gerçekleştirdikleri uygulamalar, onların özyeterlik inancını geliştirmeleri açısından büyük önem taşımaktadır (Bayrakdar, Vural-Batık \& Barut, 2016). Öğretmen adaylarının özyeterlik inancını geliştirmede önemli bir yere sahip olduğu düşünülen öğretmenlik uygulamaları (Sağır, Bilen \& Ercan, 2014), öğretmen adaylarının güçlü ve zayıf yönlerini görmelerine yardımcı olmaktadır (Tschanen-Moran, Woolfolk-Hoy \& Hoy, 1998). Aynı zamanda, bu uygulamalar öğretmen adaylarına doğrudan yaşantılar sunarak, onların özyeterlik inancını geliştirmelerine katkı sağlamaktadır (Tschanen-Moran \& Hoy, 2001). Öğretmenlik uygulamalarından sonra öğretmen adaylarından sınıftaki öğrencileri organize edebilme, iletişim kurabilme ve onları etkin olarak öğretme-öğrenme sürecine katmada deneyim kazanmaları beklenmektedir (Aktağ, 2011). Ancak, araştırma alanyazını öğretmenlik uygulamalarının öğretmen adaylarının özyeterlik inancı üzerinde anlamlı bir etkiye sahip olmadığını göstermektedir (Aktağ, 2011; Sağır, Bilen \& Ercan, 2014). Bunun yanı sıra, ilgili alanyazın öğretmenlik uygulamalarının öğretmen adayları tarafından etkili dersler arasında gösterilmediğini de rapor etmektedir (Görgen, Çokçalışkan \& Korkut, 2012). Dolayısıyla, araştırma alanyazınının bu araştırmanın bulgularını desteklemekte olduğu söylenebilir. Bu sonuç, öğretmenlik uygulamalarının öğretmen adaylarının özyeterlik inancını geliştirmede yetersiz olduğunu ortaya koymaktadır. Elde edilen bulgunun ortaya çıkmasında bazı sebeplerin etkili olabileceği düşünülmektedir. Özellikle, öğretmenlik uygulamalarının süresinin yetersizliği (Özkılıç, Bilgin \& Kartal, 2008), uygulama okullarının yeterli koşullara sahip olmamaları, rehber öğretmenlerin gerekli yeterliğe sahip olmamaları (Aslan \& Sağlam, 2018), öğretim 
elemanlarının yeterli rehberliği yapamamaları (Topkaya, Tokcan \& Kara, 2012), öğretim elemanı başına düşen öğretmen adayı sayısının fazla olması (Azar, 2003), öğretmen adaylarının kendilerini geliştirmede yeterli fırsatı bulamamaları (Çelikten, Şanal \& Yeni, 2005) ve fakülte-uygulama okulu arasındaki koordinasyon eksikliği (Aydın, Selçuk \& Yeşilyurt, 2007) gibi sebeplerin elde edilen bulgunun ortaya çıkmasında etkili olduğu söylenebilir. Bu nedenle, öğretmenlik uygulamalarının öğretmen adaylarıın yeterli düzeyde özyeterlik inancı geliştirmesi bakımından yeniden düzenlenmesi gerekmektedir. Zira, YÖK öğretmenlik lisans programlarında revizyona giderek, öğretmenlik uygulamasını tüm bölümler için iki döneme çıkarmıştır (YÖK, 2018). Bununla birlikte, MEB ise öğretmenlik uygulamalarında öğretmen elemanı başına düşen öğretmen adayı sayısını en fazla sekiz ile sınırlandırmıştır (MEB, 2018). Yapılan bu düzenlemelere bakıldığında, öğretmen adaylarının daha etkili bir biçimde yetiştirilmesinin amaçlandığı anlaşılmaktadır. YÖK'ün (2018) öğretmenlik uygulamasını her bölüm için iki döneme çıkarması öğretmen adaylarının daha uzun süre uygulama yapmasına imkân verdiği, MEB'in (2018) yaptığı değişiklikle öğretim elemanı ve rehber öğretmen ile öğretmen adayı arasındaki etkileşimi daha verimli hale getirmeye çalıştığı ileri sürülebilir. Her ne kadar gerek YÖK'ün (2018) gerekse MEB'in (2018) öğretmenlik uygulamalarına ilişkin ortaya koydukları düzenlemeler olumlu olarak değerlendirilse de, sistemin bazı sorunları içerisinde barındırmaya devam ettiği görülmektedir. Örneğin, uygulama okullarının uygun koşullara sahip olmamaları, rehber öğretmenlerin gerekli yeterlikleri taşımamaları (Aslan \& Sağlam, 2018), öğretim elemanlarının rehberlik yapmada yetersiz olmaları ve eğitim fakültelerinin rehber öğretmen seçiminde seçici davranmaması (Topkaya, Tokcan \& Kara, 2011) bu sorunlar arasında gösterilebilir. Dolayısıyla, ifade edilen bu sorunların öğretmenlik uygulamalarından elde edilmesi beklenen verimi düşürdüğü savunulabilir. Bu bağlamda, öğretmenlik uygulamaları üzerinde kısmi değişiklikler yapmaktan ziyade, uygulamaların bütüncül bir biçimde ele alınması üzerinde odaklanılması gerektiği söylenebilir.

Sonuç olarak, yapılan araştırmada öğretmenlik uygulamalarının öğretmen adaylarının mesleğe yönelik tutumunu geliştirmede etkili olduğu görülürken, bu uygulamaların onların özyeterlik inancını geliştirmede etkili olmadığı anlaşıımıştır. Bu sebeple, öğretmenlik uygulamalarının süresinin artırılmasının oldukça önemli olduğu söylenebilir. Bu şekilde, öğretmen adaylarının hem okullarda daha fazla zaman geçirerek mesleğe yönelik olarak tutumunu hem de daha fazla uygulama yapma fırsatına sahip olarak özyeterlik inancını geliştirebilecekleri düşünülmektedir. Ayrıca, uygulama okullarının seçimine özel önem verilmesi gerektiği ifade edilebilir. Nitekim, uygun koşullara sahip olmayan okullarda öğretmen adaylarının gerek mesleğe yönelik olumlu tutum kazanmaları gerekse özyeterlik inancını geliştirmeleri mümkün gözükmemektedir. Benzer bir biçimde, gerekli yeterliğe sahip olmayan öğretim elemanları ile rehber öğretmenlerin bu uygulamalar için tercih edilmemesi gerektiği önerilmektedir. Çünkü, gerekli yeterliğe sahip olmayan öğretim elemanı ve rehber öğretmenlerin öğretmen adaylarının mesleki gelişimine yönelik katkıları yeterli düzeyde olmayabilir. Bu açıdan, özellikle, öğretmenlik eğitimi almış ve mesleğinde lider ve özyeterliği yüksek olan öğretim elemanı ve rehber öğretmenlerin seçilmesi oldukça önemlidir. Bunun için, öğretim elemanı seçiminde eğitim fakültelerinin, rehber öğretmen ve uygulama okulu seçiminde ise Milli Eğitim Müdürlüklerinin gerekli hassasiyeti göstermesi gerekmektedir. Aynı zamanda, uygulama okulları ve eğitim fakülteleri arasındaki koordinasyonun daha çok artıılarak, uygulamada ortaya çıkan sorunların bu kurumların eşgüdümüyle çözüme kavuşturulmaya çalışııması büyük önem taşımaktadır. Son olarak, öğretmenlik uygulamalarının parçacı bir anlayıştan ziyade, bütüncül bir yaklaşımla yeniden ele alınarak üzerinde gerekli düzenlemelerin yapılması gerekmektedir. 


\section{References}

Akpınar, M., Çolak, K., \& Yiğit, E.Ö. (2012). Öğretmenlik uygulaması dersi kapsamında sosyal bilgiler öğretmen adaylarının yeterliklerine yönelik uygulama öğretmenlerinin görüşleri. M.Ü. Atatürk Eğitim Fakültesi Eğitim Bilimleri Dergisi, 36, 41-67.

Aktağ, I. (2011). Öğretmenlik uygulaması dersinin öğretmen yeterliği üzerine etkisi. Spor Bilimleri Dergisi, 22(1), 13-23.

Akyıldız, S. (2017). Pedagojik formasyon öğretmen adaylarının öğretim sürecinin düzenlenmesine yönelik özyeterlik inançlarının incelenmesi. Amasya Üniversitesi Eğitim Fakültesi Dergisi, 6(2), 566-598.

Aslan, M., \& Sağlam, M. (2017). Öğretmelik uygulaması dersinin uygulama öğretmenlerinin görüşlerine göre değerlendirilmesi. The Journal of Academic Social Science Studies, 62, 33-50.

Aslan, M., \& Sağlam, M. (2018). Öğretmenlik uygulaması dersinin öğretmen adaylarının görüşlerine göre değerlendirilmesi. Hacettepe Üniversitesi Eğitim Fakültesi Dergisi, 33(1), 144-162.

Auerbach, C., \& Silverstein, L. B. (2003). Qualitative data: An introduction to coding and analysis. New York: New York University Press.

Avcı, E. K., \& İbret, B. Ü. (2016). Öğretmenlik uygulaması-II dersine ilişkin okul öncesi öğretmen adaylarının görüşlerinin değerlendirilmesi. Kastamonu Eğitim Dergisi, 24(5), 2519-2536.

Aydın, R., \& Sağlam, G. (2012). Öğretmen adaylarının öğretmenlik mesleğine yönelik tutumlarının belirlenmesi (Mehmet Akif Ersoy Üniversitesi Örneği). Türk Eğitim Bilimleri Dergisi, 10(2), 257-294.

Aydın, S., Selçuk, A., \& Yeşilyurt, M. (2007). Öğretmen adaylarının okul deneyimi II dersine ilişkin görüşleri (Yüzüncü Yıl Üniversitesi örneği). Yüzüncü Yıl Üniversitesi Eğitim Fakültesi Dergisi, 5, 75-90.

Azar, A. (2003). Okul deneyimi ve öğretmenlik uygulaması derslerine ilişkin görüşlerinin yansımaları. Milli Eğitim, 159, 181-194.

Bakaç, E., \& Özen, R. (2017). Öğretmen adaylarının materyal tasarımı öz-yeterlik inanç düzeylerinin teknolojik pedagojik alan yeterlikleri bağlamında incelenmesi. Ahi Evran Üniversitesi Kırşehir Eğitim Fakültesi Dergisi, 18(2), 613-632.

Bayrakdar, U., Batık, M. V., \& Barut, Y. (2016). Özel eğitim öğretmen adaylarının öğretmen özyeterlik düzeyleri ve öğretmenlik mesleğine yönelik tutumları. Ahi Evran Üniversitesi Kırşehir Eğitim Fakültesi Dergisi, 17(2), 133-149.

Ben-Peretz, M. (2001). The impossible role of teacher educators in a changing world. Journal of Teacher Education, 52(1), 48-56.

Berg, B. L., \& Lune, H. (2011). Qualitative research methods for the social sciences (8th ed.). Boston, MA: Pearson.

Bogdan, R. C., \& Biklen, S. K. (2003). Qualitative research of education: An introductive to theories and methods (4th ed.). Boston: Allyn and Bacon.

Creswell, J. W. (2012). Educational research: Planning, conducting, and evaluating quantitative and qualitative research. Thousand Oaks, CA: Sage.

Creswell, J. W. (2013). Qualitative inquiry \& research design: Choosing among five approaches (3rd ed.). Thousand Oaks, CA: Sage.

Creswell, J. W., \& Clark, P. V. (2011). Designing and conducting mixed methods research (2nd ed.). Thousand Oaks, CA: Sage.

Çapa, Y., Çakıroğlu, J., \& Sarıkaya, H. (2005). Öğretmen özyeterlik ölçeği Türkçe uyarlamasının geçerlik ve güvenirlik çalışması. Eğitim ve Bilim, 30(137), 74-81.

Çeliköz, N., \& Çetin, F. (2004). Anadolu öğretmen lisesi öğrencilerinin öğretmenlik mesleğine yönelik tutumlarını etkileyen etmenler. Milli Eğitim, 162, 139-157.

Çelikten, M., Şanal, M., \& Yeni, Y. (2005). Öğretmenlik mesleği ve özellikleri. Erciyes Üniversitesi Sosyal Bilimler Enstitüsü Dergisi, 19(2), 207-237.

Dadandı, İ., Kalyon, A., \& Yazıcı, H. (2016). Eğitim fakültesinde öğrenim gören ve pedagojik formasyon eğitimi alan öğretmen adaylarının öz-yeterlik inançları, kaygı düzeyleri ve öğretmenlik mesleğine karşı tutumları. Bayburt Eğitim Fakültesi Dergisi, 11(1), 253-269.

Demirtaş, H., Cömert, M., \& Özer, N. (2011). Öğretmen adaylarının özyeterlik inançları ve öğretmenlik mesleğine ilişkin tutumları. Eğitim ve Bilim, 36(159), 96-111.

Denzin, N. K., \& Lincoln, Y. S. (Eds.). (2005). Handbook of qualitative research (3rd ed.). Thousand Oaks, CA: Sage.

Dikmen, M., \& Tuncer, M. (2018). Öğretmenlik mesleğine yönelik tutumun çeşitli değişkenlere göre değerlendirilmesi. Harran Education Journal, 3(1), 24-38. 
Eker, C. (2015). Öğretmenlik uygulaması dersinin sınıf öğretmeni adaylarının mesleki yeterlilikleri kazanmaları üzerine etkisi. Eğitim ve Öğretim Araştırmaları Dergisi, 4(4), 246-256.

Ekinci, N., \& Tican-Başaran, S. (2015). Okul deneyimi dersinin öğrencilerin öğretmenlik algılarına etkisi. Muğla Sıtkı Koçman Üniversitesi Eğitim Fakültesi Dergisi, 2(1), 13-24.

Elkatmış, M., Demirbaş, M., \& Ertuğrul, N. (2013). Eğitim fakültesi öğrencileri ile formasyon eğitimi alan fen edebiyat fakültesi öğrencilerinin öğretmenlik mesleğine yönelik öz yeterlik inançları. Pegem Eğitim ve Öğretim Dergisi, 3(3), 41-50.

Eraslan, L., \& Çakıcı, D. (2011). Pedagojik formasyon programı öğrencilerinin öğretmenlik mesleğine yönelik tutumları. Kastamonu Ĕgitim Dergisi, 19(2), 427-438.

Erdoğdu, M. Y., \& Kurt, F. (2012). Öğretmenlerin ölçme ve değerlendirme yeterlik algılarının bazı değişkenler açısından incelenmesi. Electronic Journal of Education Sciences, 1(2), 23-36.

Erlandson, D. A., Harris, E. L., Skipper, B. L., \& Allen, S. D. (1993). Doing naturalistic inquiry: A guide to methods. Thousand Oaks, CA: Sage.

Gall, M. D., Gall, J. P., \& Borg, W. R. (2003). Educational research: An introduction (7th ed.). Boston: Allyn \& Bacon.

Glesne, C. (2011). Becoming qualitative researchers: An introduction (4th ed.). Boston, MA: Pearson.

Gökçe, E., \& Demirhan, C. (2005). Öğretmen adaylarının ve ilköğretim okullarında görev yapan uygulama öğretmenlerinin öğretmenlik uygulaması etkinliklerine ilişkin görüşleri. Ankara Üniversitesi Eğitim Bilimleri Fakültesi Dergisi, 38(1), 43-71.

Görgen, İ., \& Çokçalışkan, H. and Korkut. Ü. (2012). Öğretmenlik uygulaması dersinin öğretmen adayları, uygulama öğretmenleri ve uygulama öğretim üyeleri açısından işlevselliği. Muğla Üniversitesi Sosyal Bilimler Enstitüsü Dergisi, 28, 56-72.

Gülşen, C., \& Seyratlı, E.(2014). Formasyon eğitimi alan öğretmen adaylarının öğretmenlik mesleğine ilişkin tutumları. Eğitim ve Öğretim Araştırmaları Dergisi, 3(3), 2146-9199.

Hacıömeroğlu, G., \& Şahin, Ç. (2011). Sınıf öğretmeni adaylarının uygulama öğretmenleri hakkındaki özel alan yeterlikleri algısı. Mustafa Kemal Üniversitesi Sosyal Bilimler Enstitüsü Dergisi, 8(15), 473-486.

Harmandar, M., Bayrakçeken, S., Kıncal, R. Y., Büyükkasap, E., \& Kızılkaya, S. (2000). Kazım Karabekir eğitim fakültesinde okul deneyimi uygulaması ve sonuçlarının değerlendirilmesi. Milli Eğitim, 148, 3-6.

HEC (1998). Fakülte-okul işbirliği. Ankara: YÖK/Dünya Bankası Yayınları.

HEC (2007). Eğitim fakültesi öğretmen yetiştirme lisans programları. Retrieved from http://www.yok.gov.tr/web/guest/icerik//journal_content/56_INSTANCE_rEHF8BIsfYRx/10279/\%2017589

HEC (2018). Öğretmen yetiştirme lisans programları. Retrieved from http://www.yok.gov.tr/ogretmenyetistirme-lisans-programlari

Howell, D. C. (2006)._Statistical methods for psychology (7th ed.). Pacific Grove, CA: Cengage Wadsworth.

İnan, Ö. G. C., \& Özgen, A. G. K. (2008). Matematik öğretmen adaylarının öğretmenlik uygulaması sürecinde öğrencilere düşünme becerilerini kazandırmadaki yeterliliklerine yönelik görüşlerinin değerlendirilmesi. Electronic Journal of Social Sciences, 7(25), 39-54.

Kana, F. (2014). Türkçe eğitiminde öğretmenlik uygulaması dersi: Bir durum çalışması. Tarih Okulu Dergisi, 7, 745-764.

Kılıç, D. (2004). Öğretmenlik uygulaması dersinin öğretmen adayları üzerine etkisinin değerlendirilmesi. Atatürk Üniversitesi Kazım Karabekir Eğitim Fakültesi Dergisi, 10, 172-184.

Koç, G., \& Demirel, Ö. (1999). Öğretmenlik uygulaması dersinin gazi üniversitesi mesleki eğitim fakültesi öğrencileri üzerindeki etkileri. Dokuz Eylül Üniversitesi Buca Eğitim Fakültesi Dergisi, 10, 27-36.

Krueger, R. A. (1994). Focus groups: A practical guide for applied research (2nd ed.). Thousand Oaks, CA: Sage.

Merriam, S. B. (1998). Qualitative research and case study applications in education. San Francisco: Jossey-Bass.

Miles, M, B., \& Huberman, A. M. (1994). Qualitative data analysis: An expanded sourcebook (2nd ed). Thousand Oaks, CA: Sage.

MoNE (2017). Öğretmenlik mesleği genel yeterlikleri. Ankara: Öğretmen Yetiştirme ve Geliştirme Genel Müdürlüğü.

MoNE (2018). Uygulama öğrencilerinin Milli Eğitim Bakanlığına bağlı eğitim-öğretim kurumlarında yapacakları öğretmenlik uygulamasına ilişkin yönerge. Retrieved from https://oygm.meb.gov.tr/meb_iys_dosyalar/2018_06/25172143_YYnerge.pdf.

Nalçacı, A., \& Sökmen, Y. (2016). Öğretmen adaylarının mesleği tercih nedenleri ve öğretmenlik mesleğine yönelik tutumları arasındaki ilişki. Ahi Evran Üniversitesi Kırşehir Eğitim Fakültesi Dergisi, 17(3), 717-727. 
Oğuz, A. (2004). Okul deneyimi I dersinin öğretmen adayları üzerindeki etkileri. Dumlupınar Üniversitesi Sosyal Bilimler Dergisi, 11, 141-162.

Öksüz, Y., \& Coşkun, K. (2012). Öğretmenlik uygulaması I-II derslerinin zihin engelliler öğretmen adaylarının özyeterlilik algılamaları üzerindeki etkisi. Ahi Evran Üniversitesi Kırşehir Eğitim Fakültesi Dergisi, 13(2), 131155.

Özaydın, T. E., Çavaş, P., \& Cansever, B. A. (2017). Sınıf öğretmeni adaylarının özyeterlik inançlarının değerlendirilmesi. Ege Eğitim Dergisi, 18(1), 1-30.

Özay-Köse, E. (2014). Okul deneyimi ve öğretmenlik uygulaması derslerine yönelik öğrenci ve öğretmen öğretim elemanı tutumları (Erzurum örneği). Dicle Üniversitesi Ziya Gökalp Eğitim Fakültesi Dergisi, 22, 1-17.

Özkan, H. H. (2012). Öğretmenlik formasyon programındaki öğretmen adaylarının öğretmenlik mesleğine ilişkin tutumlarının incelenmesi (SDÜ Örneği). Ahi Evran Üniversitesi Kırşehir Eğitim Fakültesi Dergisi, 13(2), 2948.

Özkan, H. H., Albayrak, M., \& Berber, K. (2005). Öğretmen adaylarının ilköğretim okullarında yaptıkları öğretmenlik uygulamasının yetişmelerindeki rolü. Milli Eğitim, 168, 1-26.

Özkılıç, R., Bilgin, A., \& Kartal, H. (2008). Öğretmenlik uygulaması dersinin öğretmen adaylarının görüşlerine göre değerlendirilmesi. Illköğretim Online, 7(3), 726-737.

Patton, M. Q. (2002). Qualitative research and evaluation methods (3rd ed.). Thousand Oaks, CA: Sage.

Plano Clark, V., \& Ivankova, N. (2016). Mixed methods research: A guide to the field. Thousand Oaks, CA: Sage.

Rıza, E. T., \& Hamurcu, H. (2000). Sınıf öğretmenliği bölümü öğrencilerinin okul deneyimi ve öğretmenlik uygulamasına yönelik görüşleri. Pamukkale Üniversitesi Eğitim Fakültesi Dergisi, 8, 91-97.

Sağır, M., Bilen, K., \& Ercan, O. (2014). Öğretmenlik uygulaması dersinin öğretmen adaylarının öz yeterlik ve ders anlatımlarına ilişkin algılarına etkisi. Kahramanmaraş Sütçü Imam Üniversitesi Sosyal Bilimler Dergisi, 11(2), 97-114.

Sağlam, M., \& Kürüm, D. (2005). Türkiye ve Avrupa Birliği ülkelerinde öğretmen eğitiminde yapısal düzenlemeler ve öğretmen adaylarının seçimi. Milli Eğitim, 167, 53-70.

Sarıçoban, A. (2008). Okul deneyimi ve öğretmenlik uygulaması derslerine ilişkin uygulama öğretmenleri ve öğretmen adaylarının görüşleri. Gazi Üniversitesi Gazi Eğitim Fakültesi Dergisi, 28(3), 31-55.

Semerci, N., \& Semerci, Ç. (2004). Türkiye'de öğretmenlik tutumları. Fırat Üniversitesi Sosyal Bilimler Dergisi, 137, 137-146.

Shavelson, R. J. (2012). Statistical reasoning for the behavioral sciences (3rd ed.). Boston: Allyn \& Bacon.

Şişman, M., \& Acat, B., M. (2003). Öğretmenlik uygulaması çalışmalarının öğretmenlik mesleğinin algılanmasındaki etkileri. Fırat Üniversitesi Sosyal Bilimler Dergisi, 13(1), 235-250.

Tarman, B. (2012). Öğretmenlik deneyimi dersinin öğretmen adaylarının öğretmenlik mesleğine yönelik inançlarına etkisi. Kuram ve Uygulamada Eğitim Bilimleri, 12(3), 1951-1973.

Tashakkori, A., \& Teddlie, C. B. (1998). Mixed methodology: Combining qualitative and quantitative approaches. Thousand Oaks, CA: Sage.

Taşkın, Ç. Ş., \& Hacıömeroğlu, G. (2010). Sınıf öğretmeni adaylarının özyeterlik inançları: Nicel ve nitel verilere dayalı bir inceleme. Inönü Üniversitesi Eğitim Fakültesi Dergisi, 11(1), 21-40.

Topkaya, Y., Tokcan, H., \& Kara, C. (2012). Öğretmenlik uygulaması dersi hakkında sosyal bilgiler öğretmen adaylarının görüşleri. The Journal of Academic Social Science Studies, 5(7), 663-678.

Toprakçı, E. (2003). Okul deneyimi Il dersinin teori ve pratiği. Eğitim Araştırmaları, 10, 146-152.

Tschannen-Moran, M., \& Hoy, A. W. (2001). Teacher efficacy: Capturing an elusive construct. Teaching and Teacher Education, 17(7), 783-805.

Tschannen-Moran, M., Hoy, A. W., \& Hoy, W. K. (1998). Teacher efficacy: Its meaning and measure. Review of Educational Research, 68(2), 202-248.

Üstüner, M. (2006). Öğretmenlik mesleğine yönelik tutum ölçeğinin geçerlik ve güvenirlik çalışması. Kuram ve Uygulamada Eğitim Yönetimi, 45(45), 109-127.

Yalçın, İ. E., \& Akay, C. (2015). Eğitim fakültesi ve pedagojik formasyon sertifika programlarında öğrenim gören öğretmen adaylarının öğretmenlik mesleği yeterliklerine yönelik görüşleri. Ahi Evran Üniversitesi Kırşehir Eğitim Fakültesi Dergisi, 16(2), 179-197.

Yenice, N., \& Alpak-Tunç, G. (2016). Pedagojik formasyon programına katılan öğretmen adaylarının öğretmenliğe ilişkin tutumları ile mesleki öz yeterliklerinin incelenmesi. Atatürk Üniversitesi Kazım Karabekir Eğitim Fakültesi Dergisi, 35, 144-155.

Yıldırım, A., \& Şimşek, H. (2008). Sosyal bilimlerde nitel araştırma yöntemleri (6th ed.). Ankara: Seçkin Publications. 
